\title{
Entrepreneurship Education in Bhutan: Perception, Culture and
}

\section{Challenges}

Karma Utha ${ }^{1 *}$, Sonam Rinchen ${ }^{1}$, Bhupen Gurung ${ }^{1}$, Ganeshman Gurung ${ }^{1}$, Tshewang Rabgay ${ }^{2} \&$ Changa

$$
\text { Dorji }^{3}
$$

${ }^{1}$ Samtse College of Education, Royal University of Bhutan, Bhutan

${ }^{2}$ Samtse Higher Secondary School, Samtse, Bhutan

${ }^{3}$ Royal University of Bhutan, Bhutan

* Karma Utha, E-mail: kutha.sce@rub.edu.bt

Received: September 26, 2016 Accepted: October 17, 2016 Online Published: November 3, 2016

doi:10.22158/wjer.v3n2p460 URL: http://dx.doi.org/10.22158/wjer.v3n2p460

\begin{abstract}
The present study was undertaken to determine the perception of Bhutanese students towards entrepreneurship and the influence of entrepreneurship in their career choice by a team of lecturers from Samtse College of Education and a teacher from the Samtse Higher Secondary School. It was a multifaceted research involving survey, interviews, focus group interviews and document analysis. The samples include 921 students [19 diploma, 248 undergraduate, 654 school students (460=HSS \& 194=MSS)], currently studying in the schools, colleges and VTIs under Samtse, Chhukha and Thimphu Dzongkhags. The major findings include: perception of students is inclined more towards entrepreneurship second to government jobs, students and parents are aware of the increasing unemployment scenario in Bhutan, minimal focus on entrepreneurship education in the school and university level curriculum, and the pedagogical practices doesnot adequately favour entrepreneurship knowledge and skill development. Some of the recommendations are a need to include entrepreneurship education in the school curriculum right from primary education, and to disseminate information related to entrepreneurship among students in all the schools and colleges.
\end{abstract}

\section{Keywords}

Entrepreneurship, Bhutan, career, curriculum, perception

\section{Introduction}

Entrepreneurship is a dynamic process of vision, change, and creation (Kuratko \& Hodgetts, 2004). It is more than the mere creation of business. Entrepreneurship is concerned with establishing new activities and being able to perceive new opportunities and making them work in a number of social areas. Entrepreneurship is referred to as "any attempt at new business or new venture creation, such as 
self-employment, a new business organization, or the expansion of an existing business, by an individual, a team of individuals, or an established business" (Global Entrepreneurship Research Association [GERA], 2013). Entrepreneurship requires an application of energy and passion towards the creation and implementation of new ideas and creative solutions.

Entrepreneurship education, on the other hand, is learning to understand entrepreneurship, learning to become entrepreneurial and learning to become an entrepreneur (Hytti, 2002). Further, entrepreneurship education is about learning for entrepreneurship, learning about entrepreneurship and learning through entrepreneurship (Gibb, 2005). The purpose of entrepreneurship education is to make students take more responsibility for themselves and their learning, to try to achieve their goals, be creative, discover existing opportunities and in general to cope in our complicated society and take an active role in job markets and consider entrepreneurship as a natural career choice. Entrepreneurship education involves developing the essential attributes of entrepreneurs such as the willingness to take calculated risks in terms of time, equity, or career; the ability to formulate an effective venture team; the creative skill to marshal needed resources; fundamental skill of building solid business plan; and finally, the vision to recognize opportunity where others see chaos, contradiction, and confusion (Kuratko \& Hodgetts, 2004). The positive role of entrepreneurs in the economy is well known; they create value, new jobs, and are often associated with innovation. In the time of crisis and high youth unemployment, the role of entrepreneurs is especially important. Bhutanese economy is fast changing. Bhutan has progressed in all fronts of the development since the 1960s with the initiation of a concrete government strategy for socioeconomic development. The rapid growth and expansion of the Bhutanese economy has resulted in the improved living standards of the citizens. However, like in any other developing economies, the growth of Bhutanese economy is not without a problem. It has been characterized by increasing youth unemployment. The unemployment situation emerged in the late 1990 s, which was $1.4 \%$ and has increased to $2.9 \%$ in 2013 (Gross National Happiness Commission [GNHC], 2013). Today, it has become a pressing national issue. One of the salient features of the unemployment in Bhutan is the youth unemployment, which was $9.6 \%$ in 2013 (ibid). In the face of such high youth unemployment, the concept of entrepreneurship today has become more important and relevant than ever before.

Entrepreneurship education is increasingly looked upon as solution to youth unemployment. This is because entrepreneurship knowledge and skill leads to increased economic efficiencies, brings innovation to the market, creates new jobs, and raises employment levels (Shane \& Venkataraman, 2000). This involves equipping Bhutanese youths with relevant knowledge and skills to match employers' needs in the increasingly competitive job market with relevant entrepreneurship knowledge and skills. The government of Bhutan, in recent years, has placed greater commitment to enterprise and entrepreneurial activity, as part of broader economic goals. Entrepreneurship has become a key theme in major policy documents such as the Economic Development Policy (2010), National Human Resource Development Policy (2010) and Cottage, Small and Medium Industry Policy (2012), Cottage, Small and Medium Industry Development Strategy (2012-2020) and Action Plan (2012-2014). Further, besides the 
government consistently promoting the growth of the private sector, there have also been specific key initiatives to stimulate growth of cottage and small manufacturing industries and non-formal commercial sector through the provision of financial supports, for example, the establishment of the Business Opportunity and Information Centre (BOIC) in 2014.

While the benefits of entrepreneurial education have been highlighted by both researchers and educators (Kuratko, 2005; Pittaway \& Cope, 2006; Jones \& English, 2004) the popular belief surrounding Bhutanese education system has been that our current education system does not meet the needs of students and employers and most students tend to see education as a way to obtain jobs in the public sector which cannot accommodate all of them (Rinchen, 2014). On the other hand, as cited in Karimi (2012), most of the empirical studies conducted in the world indicate that entrepreneurship can be taught and that education can foster entrepreneurship (Falkang \& Alberti, 2000; Gatewood et al., 2002; Harris \& Gibson, 2008; Henry et al., 2005; Kirby, 2002; Kuratko, 2003, 2005; Mitra \& Matlay, 2004). This demands integrating entrepreneurship education in the school and college curriculum because learning about and experiencing entrepreneurship whilst still at schools and colleges can have several benefits. Among others, it gives students an alternative career option and the confidence to set up their own business or social enterprise. In view of this, the government of Bhutan has recently initiated a number of measures to overhaul our education system to make it more realistic and practical to ensure a population which is flexible, well qualified for working life including enterprising (see Bhutan Education Blueprint 2014-2024, 2014).

Although the importance of entrepreneurship education has been widely acknowledged and many initiatives are put in place by the government, there have not been many studies conducted on this subject in the context of Bhutan. Therefore, this study aims to explore the status of entrepreneurship education in Bhutan with special reference to the perception of the students towards entrepreneurship, entrepreneurship culture and opportunities and challenges in fostering entrepreneurship. Accordingly, the following research questions were posed:

1) What is the perception of Bhutanese students towards entrepreneurship and the influence of entrepreneurship on their career choice?

2) What factors influence entrepreneurship among Bhutanese students?

3) How various colleges, institution and school education influence entrepreneurship in Bhutan? and

4) What are the opportunities and challenges in fostering entrepreneurship in Bhutan?

The findings and recommendations of this study are expected to be significant to the multiple stakeholders and policy makers ranging from educationist to promoters of entrepreneurship in the country. 


\section{Method}

\subsection{Introduction}

The purpose of this research was to study the college and school student's perceptions of entrepreneurship and how the college and school activities influence their entrepreneurship skills in Bhutan. This section describes the methods and techniques used in the collection of data, the research design, population and sampling, research instruments used and how data were analysed.

\subsection{Research Design}

The research design used for the study was mixed method design. The quantitative data were collected by administering questionnaires to colleges, Vocational Training Institutes (VTI) and school students. The qualitative data was garnered by interviewing selected students, teachers, parents, principals of the colleges and schools, and officials from the local government.

\subsubsection{Population and Sample}

The target population for this study comprised eight categories of participants: school students of classes IX to XII from the Middle Secondary Schools (MSS) and Higher Secondary Schools (HSS) in Samtse, Chhukha, and Thimphu Dzongkhags, selected students from the College of Natural Resources, College of Science and Technology, Gedu College of Business Studies, Samtse College of Education, Royal Thimphu College and Royal Institute of Management, selected students from National Institute of Zorig Chusum and Choki Traditional Arts School, school principals, school teachers, college lecturers, parents and officials from the local governance.

A total of 19 diploma students, 248 undergraduate students, 654 school students (460=HSS \& 194=MSS), currently studying in the schools, colleges and VTIs in the three Dzongkhags were asked to respond to a detailed survey questionnaire (See Appendix A Survey Questionnaires). Semi-structured interviews were carried out with college lecturers $(n=2)$, local government officials $(n=2)$, the school principal $(n=1)$, school teachers $(\mathrm{n}=4)$ and parents $(\mathrm{n}=3)$ [see Appendix B Interview Protocol]. Focus group interviews were conducted with each of the four focus groups from two HSS in Samtse Dzongkhag [Appendix D-Focus Group Interview Protocol]. The participants in the interviews were selected using a stratified random sampling method. The participants in focus group interviews were class IX and XI students as class X and XII students were taking the final examination during the time of the interview.

This study draws on multiple tools that are designed to generate rich data. The tools used in this study are questionnaires, semi-structured interviews, focus group interview and documents as detailed below.

\subsubsection{Data Sources}

This study accessed multiple data sources to develop rich understandings about the respondent's perceptions of the entrepreneurship and the influence of school and college activities on the respondents' entrepreneurial skills. These data sources included questionnaires, interviews, focus group interviews and documents.

The questionnaires were based on 7-point scale responses: Strongly Disagree (SD), Disagree (D), Agree (A), Strongly Agree (SA), Neutral (N), Don't Know (DK), and Not Applicable (NA). Section A 
demanded demographic information on the personal details of the students and Section B contain items on school culture, research development, government support and policy, student's general perceptions, support from family, friends and relatives on entrepreneurship.

A second source of data was garnered from semi-structured interviews of selected college lecturers, school teachers, school principals, and local government officials. The interview is one of the most efficient techniques to collect qualitative data. The qualitative interview allows people to convey to others a situation from their own perspectives. Interviews are conversations with structure and purpose that are defined and controlled by the researcher (Rubin, 1995).

The third data source include focus group interviews of four groups of students with each group comprising of 5-8 students. Focus group interview is one of the most efficient techniques to collect qualitative data from a group of people instead of only one person in a short span of time. The process is enjoyable for the participants, for they share their experiences through lively discussion. It also acts as a process of check and balance by making it easy to spot forged views, thus authenticating the quality of the data (Rinchen, 2001).

The fourth source of data is document analysis, which is one of the widely employed research tool. Documents such as school curriculum framework, school textbooks, college module descriptors, policy guidelines, websites and pamphlets were referred to find to what extent entrepreneurial knowledge and skills were integrated into the school and college curriculum.

\section{Result}

The need for entrepreneurship education in the Bhutanese context seems to be urgent, as the employment opportunities are not growing proportionately in relation to the number of students graduating from educational institutions. Entrepreneurship as a career alternative to Bhutanese youth is one of the government's strategies to address the problem of unemployment in the country. The current practice of offering entrepreneurship skills and knowledge to the few out of school youth and university graduates may not be the long term solution to address the unemployment issue. Entrepreneurship education must permeate in our education system across all levels and disciplines to develop an entrepreneurship culture in Bhutan. The basic concept and knowledge on entrepreneurship among students seems to be inadequate at the moment. The existing curriculum across all levels and disciplines contains minimal knowledge of entrepreneurship. Pedagogical approaches are more teacher-centric, limiting student's creativity, communication skills and innovation. It is only in some co-curricular activities where entrepreneurial ideas and activities are incorporated. Given these scenario in school and colleges, it would be unfair to expect a large number of promising entrepreneurs to emerge from educational institutions in future.

Students and parents are aware of the fact that the job market is becoming competitive every year and they are now open to the idea of taking alternative career options such as entrepreneurship. Stakeholders such as students, educators, parents and local government officials feel the need of empowering students with entrepreneurship skills and knowledge. 


\section{Recommendations}

Developing entrepreneurship culture among students requires a multi-faceted approach. As such, we recommend multiple approaches through which, entrepreneurship culture can be effectively developed among the students in educational institutions.

a. Entrepreneurship education is not adequately integrated into the existing curriculum of the schools and colleges. We therefore would suggest the following to the Ministry of Education:

- There is a need to integrate entrepreneurship education across all levels of education with emphasis on fostering entrepreneurial skills, creativity and innovation.

- Financial literacy needs to be promoted among the students, by introducing a separate optional subject in classes IX and X, which should include basic financial terminologies and concepts.

- Pedagogical approaches needs to be more learner centric engaging students actively in the learning process. For this to materialize, the contents in the syllabus must be slimmer, so as to provide space for the teacher to use varieties of approaches effectively and to make learning meaningful.

- Assessment practices in schools and colleges needs to shift from exam based system (summative assessment) to formative assessment.

- The study indicates that only a few clubs in the schools deals with activities that promote entrepreneurial knowledge and skills among students and teachers. Schools must streamline and add rigour to club activities to promote entrepreneurship skills among students. Moreover, teachers must be trained with entrepreneurship knowledge and skill.

b. Royal Monetary Authority of Bhutan has been promoting financial Literacy in educational institutions, but our study reveals that the financial literacy among students seemed to be very poor, as such we would like to recommend the following:

- RMA should expand its financial literacy programmes (both in terms of width and depth) across all the educational institutions in the country. It must collaborate with educational and vocational institutions in delivering financial related information as a part of "financial inclusion strategy".

- It must encourage financial institutions within its ambit to promote their financial products and services in the locality, particularly in educational institutions.

c. The officials from local government involved in our study lack understanding of basic government programmes and policies related to entrepreneurship. Moreover, the financial literacy among these officials seemed to be inadequate. Since they are key figures in the community, entrepreneurship related programmes and policies (including financial literacy programmes) must be made available to them.

d. In spite of the entrepreneurship activities being promoted in the colleges through modules and other avenues, the students' mindset is still oriented towards government jobs. Therefore, the colleges should come up with entrepreneurial activities that are practical and relevant. 


\section{Discussion}

Two general themes were developed from the analysis of the data:

Theme 1: Perceptions of students on entrepreneurship;

Theme 2: Entrepreneurship culture in the schools and colleges.

These two themes are elaborated further through a series of sub-themes such as Perceptions of students on entrepreneurship (Employment issue, Career preference, Parental influence on student's career choices and Entrepreneurship as career option) and Entrepreneurship culture in the schools and colleges (Curriculum, Pedagogy, Co-curricular activities, Lecturer/teacher encouragement and ability to speak in Multi language).

\subsection{Perceptions of Students on Entrepreneurship}

Students perception is an important factor in framing policies and programmes on employment and entrepreneurship in the country. This section focuses on the perception of the students on employment scenario, career choices and entrepreneurship conditions in the country. Stakeholders such as parents, teachers, lecturers, principal and the local government officials play an important role in developing an entrepreneurial mindset among the students. Hence, their views are also taken to supplement students' views on the current employment and entrepreneurship scenario in the country.

\subsubsection{Employment Issue}

Unemployment in Bhutan has become a persistent national challenge in the last few years. The Prime Minister of Bhutan, in his report to the nation in 2014 stated that, "unemployment is a real challenge and it is the young people who are increasingly finding it difficult to get jobs". Increasing numbers of youth are being churned out of educational institutions every year, into an already saturated job market, leaving many youths unemployed. According to the $12^{\text {th }}$ National Labour Force Survey [NLFS] (2014), the national unemployment figure stood at 9,173 in 2014. The female unemployment figure was recorded at 5,546 , which is 1.6 percent higher than the number of male unemployed at 3,627. Table 1 below shows the perception of the students towards the causes of unemployment in the country.

Table 1. Perception of Students on Causes of Unemployment

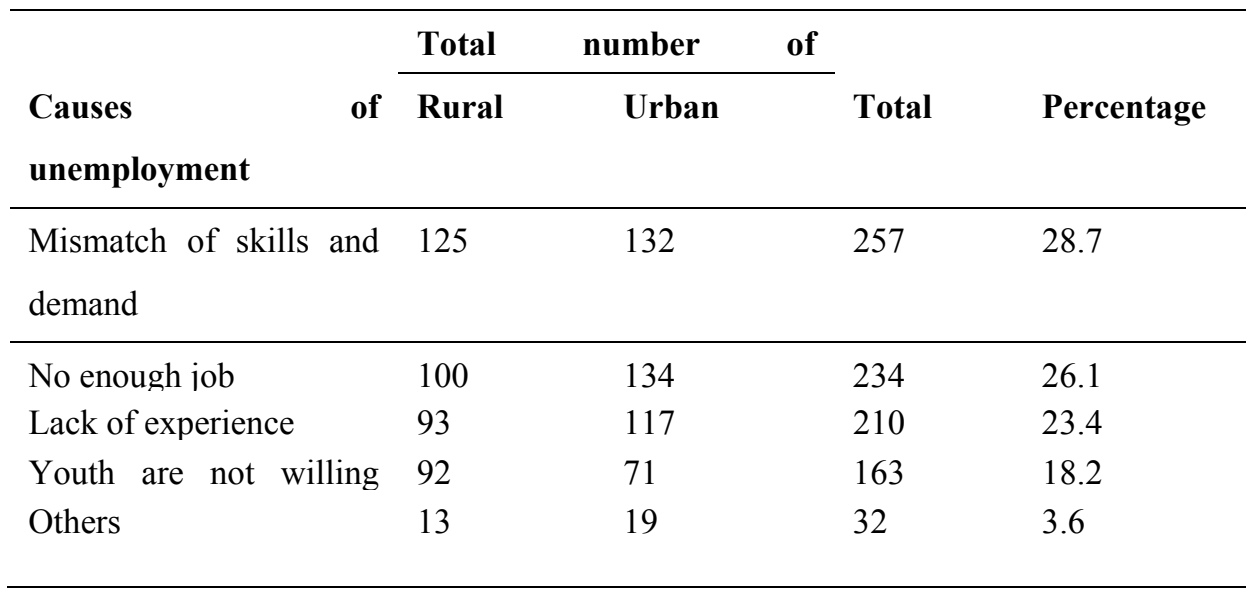


Table 1 shows that factors such as "Mismatch of skills and market demand" (28.7\%), "Not enough job" (26.1\%) and "Lack of experience among job seekers" (23.4\%) are the top three causes of unemployment in the country. However, "Mismatch of skills and market demand" is perceived by the respondents as the main cause of unemployment in the country. The Social and Cultural Affairs committee of the National Council reviewing the National Employment Policy (2013) states that there is a mismatch between supply and demand of human resources which validates the perception of the respondents (see http://www.thebhutanese.bt).

The data from the $12^{\text {th }}$ NLFS, 2014 , reveals that almost $85 \%$ of the total unemployed youth are educated, which indicates the mismatch of skills with the job market. The type and quality of education that are imparted to our youth seems to be making them impotent in the job market. The Prime Minister in his report to the nation in 2014 too indicated the phenomena as a dichotomy between the jobs that are available in the market and the jobs that are being sought. Employment of the youth and students in particular is largely defined by the width and depth of the country's economy. In 2014, the country's economy experienced a real Gross Domestic Product (GDP) growth of 5.4\% (Annual Report 2014-2015, Royal Monetary Authority of Bhutan [RMA]). The growth was largely attributed by the tertiary sector with a contribution of $3.8 \%$, while the contribution of the secondary sector to real GDP fell from $1.7 \%$ in 2013 to $1.4 \%$ in 2014 . Similarly the growth in primary sector has remained unchanged at $0.3 \%$ since 2011. Given these scenario of the Bhutanese economy, most of the employment and career opportunities are created in the tertiary sector. The other two sectors, i.e., primary and secondary have not been able to create space for the graduates seeking employment. Another factor is that our youth are inclined more towards government jobs, which are perceived to be more secure as compared to the jobs in the private sector. The concept of self-employment as a career choice is relatively new to the Bhutanese youth.

\subsubsection{Career Preference}

The career preferences of the students are largely defined by societal and family influences. One student respondent, when asked about his career preference, puts the situation as; "I want to become a doctor, as they are respected in the society" (Focus Group 2). The societal valuation and stratification of the profession determines the career preference of the students. Doctor, Engineer, Army officer and teacher are regarded as high value professions by the society in general, which in turn make the students to opt for such professions. These professions are usually government jobs which ensure stability, recognition and security. The following excerpt from the focus group interviews reveal the situation:

We would prefer to work as civil servants in government jobs, as there is job security. If government jobs are not available, then we would work in private organization. Even our parents encourage us to take up government jobs (Focus Group 1, 2, 3 \& 4).

The reasons cited by the students for taking up employment that too in the government sector is mainly due to the job security. It is also because of the fact that government jobs are not as demanding (i.e., instability of the job, long working hours and poor remuneration) as compared to the jobs in the private sector. Another reason why most of the students opt for the government job is due to the slow growth of 
the private sector. The private sector in Bhutan lacks width and depth in terms of its operation. The terms and conditions of employment such as instability of the job, long working hours and poor financial benefits (including pension benefits) in the private sector are often unfavorable as compared to the government jobs. Table 2 below shows the students' career preferences.

Table 2. Preferred Career Choices of the Students

\begin{tabular}{|c|c|c|c|c|c|}
\hline \multirow[t]{2}{*}{$\begin{array}{l}\text { Students } \\
\text { choices }\end{array}$} & \multirow[t]{2}{*}{ career } & \multicolumn{2}{|c|}{$\begin{array}{l}\text { Total number of } \\
\text { respondents }\end{array}$} & \multirow[t]{2}{*}{ Total } & \multirow[t]{2}{*}{ Percentage } \\
\hline & & Rural & Urban & & \\
\hline Employment & & 249 & 178 & 427 & 66.8 \\
\hline Start own business & & 70 & 64 & 134 & 21 \\
\hline Farming & & 4 & 3 & 7 & 1.1 \\
\hline Others & & 35 & 36 & 71 & 11.1 \\
\hline
\end{tabular}

The majority of the students (66.8\%) expressed that they would like to seek "employment" after their graduation. A small section (21\%) of the students prefer to start their own business followed by others $(11.1 \%)$ and only $1.1 \%$ in farming. The rural students have a strong inclination towards employment as a career option as compared to their urban counterparts. When asked about the preferred sector of employment, $89 \%$ of them preferred to seek government jobs, $6 \%$ in the private sector, $3 \%$ in corporations and $1 \%$ each for Non Government Organisations (NGO) and other professions as reflected in Figure 1.

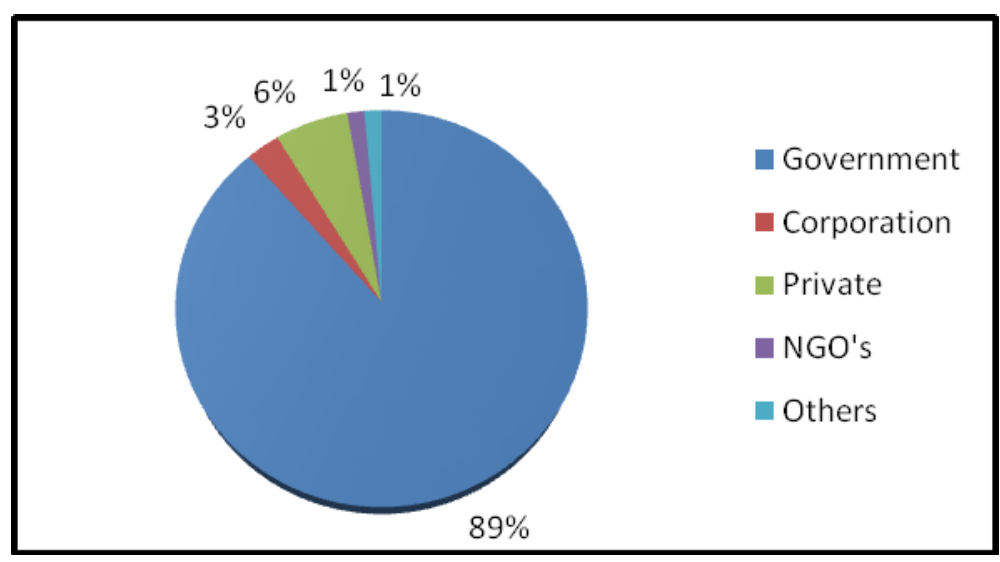

Figure 1. Students Preferred Sector of Employment

When asked about taking entrepreneurship as a career option, students in one focus group put it as follows: 
We have not thought about starting our own business, but if we have to then we would like to work under others business set up or friends business instead of starting our own. The reason is that we have no idea about the business scenario at the moment (Focus Group 2).

The students in the other focus group also shared the same views; "Yes, somebody must show us the way to do business and provide the money" (Focus Group 1).

Professions such as entrepreneurship and farming are relatively considered to be low esteemed. These professions demand lots of investment and resources such as time, hard work, risk and finance, and the returns are not always favorable and stable. Obviously, government job becomes the first career option for the students after their graduation.

\subsubsection{Parental influence on Student's Career Choices}

Parents and family has a strong influence on the career choices of the students. Most of the students take the wisdom and advice of their parents to make this critical decision on what they would like to pursue in future. Parents would like their children to opt for those careers which are secure and stable, i.e., the government job. For instance, a parent expressed, "as a mother, I want my kids to be under government service because government jobs are secure and they will get their payment on time" (Parents 1). Similar views were also echoed by the local government officials (also parents): "If they get a government job they can take up government job and if they want to start a business they can also do that as a secondary option" (Local Government $1 \& 2$ ).

To sum up, two reasons are prominent for preferring government jobs. Firstly the government jobs are secure and stable and secondly taking up alternative career option such as entrepreneurship is unstable and risky. As put by one of the parents, "One needs to take a huge risk in starting up a business. Starting up a business is not an easy task in Bhutan as Bhutan is still developing". However, most of the parents do agree that the job market in Bhutan is getting saturated not only in the government sector, but also in the private sector. They are now slowly coming to terms with this reality of finding an alternative career option for their children. This is made explicit by one of the Local Government officials: ...many youth who are not able to qualify for higher learning and are seeking government jobs. Instead of waiting for a government job opportunity, they should take the opportunity of availing loan from the BOIC and start businesses so that they can become self reliant (Local Government 1).

He further adds that, "Youth should commercialize agriculture products. If youth take up entrepreneurship in agriculture, it would give them a great future".

\subsubsection{Entrepreneurship as a Career Option}

Despite all the initiatives and encouragement from the government, Non Governmental Organisations and private institution, the growth of entrepreneurs in Bhutan is quite limited and slow at the moment. Majority of the students prefer "employment" and few opt for entrepreneurship. Given the limited size of the economy, the current practice of offering "entrepreneurship" as an alternative to the unemployed educated youth' seems to bear an inherent flaw in itself as the youth confronts it as the last resort due to failure to land a secure job. However, students in general seem to have a positive outlook towards 
entrepreneurship as they now realize that their options are limited in finding a secure job. For instance, some students expressed:

Entrepreneurship is good for the country as it helps to increase the country's income. Better quality of goods and services are available to the people. It would generate employment opportunities for the youth (Focus Group 1).

The concept of self-employment is relatively new in the Bhutanese context, and both students and parents now seem to accept the fact that jobs are not guaranteed after their graduation. They realize the fact that finding other career options are inevitable. Students now are open to the idea of taking up other career alternatives such as entrepreneurship, but the poor information and lack of skills are barriers for them to pursue entrepreneurship as a career option. This is articulated by some of the students during focus group as indicated below:

We have not thought about starting their own business, but if we have to then we would like to work under others business set up or friends business instead of starting their own. The reason is that we have no idea about the business scenario at the moment (Focus Group 2).

Students are interested in taking entrepreneurship as a career option, especially when the employment opportunities both in government as well as in the private sector are becoming competitive. However, the lack of entrepreneurship skill and information is putting the students in a precarious situation. On one hand the employment opportunities are not growing proportionately to the number of graduates that are being produced by the educational institutions, and on the other, the students are inadequately equipped with entrepreneurship skills and related information. Imparting entrepreneurship skill and information has now become a necessity and must be firmly embedded in the curriculum in educational institutions. The following opinions were outlined by teachers when interviewed:

Farmers around this locality grow cardamom, which fetches good income for them. Whenever I talk about the importance of education in the class, many students express that they want to become educated farmer because they know that cardamom cultivation is lucrative activity. Other than this, I don't think my students have enough idea about entrepreneurship (Teacher $3 \& 4$ ).

Though, the students would aim for employment in government jobs, but in the event of not finding one, they may consider taking up entrepreneurship as alternative career option. In our study, $21 \%$ of the students preferred to "start the business", which is the second career option. A similar study on perception of unemployed youth, conducted by Ministry of Labour and Human Resources (MOLHR) in collaboration with the United Nation Development Programme (UNDP) on unemployed youth perception survey in 2014 shows that $5.4 \%$ preferred self-employment or to start a business. To expect entrepreneurship to be their first career option among majority of the students would be naïve and impractical, given the macroeconomic framework of the country and the type of education that are being imparted in the educational institutions. Any students (or parents) would like to opt for the government job. The concept of self-employment through entrepreneurship needs to be promoted, so that the students can fall back onto the entrepreneurship skills and information to start their own business, if they fail to 
secure meaningful employment. Likewise, the financial literacy seemed to be poor among the students in general. The basic concepts and terminology used in the context of entrepreneurship, (for example matters related to obtaining finance) needs to be made familiar to the students, either through the content by having a separate subject/module or by organising awareness programmes. The Royal Monetary Authority of Bhutan has been organising financial literacy awareness programmes across the country, but the effect seems to be minimal. The Table 3 shows the reasons for not taking up the entrepreneurship by the students.

Table 3. Reasons for Not Willing to Take Entrepreneurship by the Students

\begin{tabular}{lllll}
\hline $\begin{array}{l}\text { Students not willing to } \\
\text { take entrepreneurship }\end{array}$ & $\begin{array}{l}\text { Total } \\
\text { respondents } \\
\text { Rural }\end{array}$ & $\begin{array}{l}\text { number } \\
\text { Urban }\end{array}$ & Total & Percentage \\
\hline Lack of skills & 141 & 123 & 264 & 27.6 \\
Lack of finance & 89 & 121 & 210 & 22 \\
Not willing to take risk & 84 & 97 & 181 & 19 \\
Lack of social/family & 54 & 76 & 130 & 13.6 \\
support & & & & \\
Lack of & & 52 & 94 & 9.8 \\
opportunities & 42 & 53 & 76 & 8 \\
Lack of support from the & 23 & & & \\
government & &
\end{tabular}

Table 3 shows the main causes of students not willing to take entrepreneurship in the country is the "Lack of skills" $(27.6 \%)$, followed by "Lack of Finance" $(22 \%)$ and the "Youth not willing to take risks" $(19 \%)$.

A number of entrepreneurship courses such as BEC (Basic Entrepreneurship Course), CEC (Comprehensive Entrepreneurship Course), AEC (Advance Entrepreneurship course) are offered by MOLHR to empower the youth with entrepreneurship skills. Similarly, DHI (Druk Holdings \& Investment), BOIC (Business Opportunity and Information Centre) and Loden Foundation offer entrepreneurship skills at regular intervals to Bhutanese youth with promising business ideas. However, these entrepreneurship knowledge and skills have not yet been rooted in our educational setting. Basic knowledge on entrepreneurship, policies and programmes related to entrepreneurship needs to be made familiar to the students in educational institutions, so that the students are motivated to take up entrepreneurship as a career option in the future.

Another reason cited by the students for not taking up entrepreneurship as a career option is the lack of finance. Access to cheap and adequate finance is one critical factor which determines the establishment 
of any business venture. Lack of information and difficulty in securing cheap and adequate finance hinders potential entrepreneurs to translate their business ideas and plan into a successful venture. Government through BOIC have been funding business plans and proposals of the people from all the Dzongkhags, yet the finding reveals that more needs to be done. Financial institutions, particularly the commercial banks in the country need to shift their modus operandi of confining themselves to commercial hubs and spread across the country, so that people have easy access to finance.

\subsection{Entrepreneurship Culture in the Schools and Colleges}

Entrepreneurship culture in the schools and colleges refers to academic activities (i.e., curriculum, pedagogy, lecturer/teacher encouragement) and non-academic activities (co-curricular and ability to interact in multiple languages) that the students participate in.

The findings reveal that the activities that contribute to entrepreneurship culture in the schools and colleges are curriculum, pedagogy, co-curricular activities, lecturer/teacher encouragement, and ability to speak in multi language. How these activities promote entrepreneurship concepts, qualities and knowledge in the students are discussed below:

\subsubsection{Curriculum}

Curriculum refers to academic content being offered in schools and colleges as part of a course or programme. Here the curriculum study is discussed under two categories, namely school curriculum (grade PP-12) and University curriculum (degree level).

1) School Curriculum

School education in Bhutan comprises of primary (grade PP-6) and secondary education (grade 7-12). The secondary education is further classified as lower secondary (grade 7-8), middle secondary (grade 9-10) and higher secondary (grade 11-12). In the primary education the key learning areas include, Dzongkha, English, Mathematics, Science, Social Studies, Environmental Studies, Arts Education, and Health and Physical Education. These subjects emphasise on building basic numeracy skills, literacy skills, scientific concepts, health education and environment awareness. The lower and middle secondary education is essentially a continuation and progression of the primary education syllabus. The key learning areas in these levels include English, Mathematics, Dzongkha, Biology, Chemistry, Physics, General Science, History, Civics, Geography, Economics, Information Communication and Technology, Media Information Literacy, Environmental Science, and Agriculture for Food Security. The higher secondary education offers three study streams: Science, Arts and Commerce. The subjects in the science stream include English, Dzongkha, Mathematics, Biology, Chemistry and Physics. The Commerce stream subject comprises of English, Dzongkha, Mathematics, Economics, Commerce and Accountancy. In the Arts stream, the subjects are English, Dzongkha, Economics, Geography, History and Civics. At the higher secondary level, students enroll in only one of the streams.

The document analysis revealed that the primary curriculum focus more on developing basic entrepreneurship skills such communication and numeracy. However, in the lower and middle secondary level, two subjects namely Economics and Agriculture for Food Security include entrepreneurship 
concepts and ideas of business creation. Economics treats theoretical concepts and basic economic terms in the light of their application to Bhutanese economy. The impact of the neighboring South Asian economy and changing international economic scenario in the Bhutanese economy is also considered (Curriculum and Professional Support Division [CAPSD] \& Bhutan Board of Examination [BBE], 2010). These concepts and terms would contribute to understanding entrepreneurship and how it might contribute to the economy of the country. But there are no continuation and progression of the entrepreneurship concepts across the grades. The Agriculture for Food Security subject aims at providing the scope of employment and entrepreneurship through various farming techniques such as poultry, piggery, goat farming, pasture development and crop production (Department of Curriculum and Research Division [DCRD] \& Council for Renewal Natural Resources for Research [CRNRR], 2014). Unlike some European Union countries such as Greece, Belgium and Austria, where entrepreneurship is introduced as a course at the secondary level (Entrepreneurship Education at School in Europe, 2012), entrepreneurship is not taught as a subject on its own in the higher secondary school education in Bhutan. However, business subjects in the Commerce and Arts streams such as Economics, Commerce and Accountancy include concepts which may contribute to building entrepreneurship knowledge and attitude. The grade 11 and 12 Economics focus on economic theory in relation to Bhutanese economy and also intends to enable students to compare the theories with the real situation prevailing in the Bhutanese and global economic system (CAPSD \& BBE, 2012). Accountancy is another business subject studied in the commerce stream in grade 11 and 12. It focuses on the basic concepts of accounting, principles and rules of accounting formats of journals, ledger, trial balance, subsidiary books like cash books having different columns, petty cash book, etc. They also include concepts of joint venture, partnership accounts, joint stock, company account, financial statement analysis, ratio analysis, and others (ibid). Although, these concepts may be necessary for entrepreneurship, no relation has been drawn between the concepts and entrepreneurship. Another business subject studied in class 11 and 12 is Commerce. Like in Economics and Accountancy, Commerce does not treat entrepreneurship as a separate chapter. It deals with the theory and practice of business, trade and industry; theoretical foundations, organising, managing and handling operations of a business firm; important aspects of the commercial world; and activities of commerce in marketing of goods and services (ibid).

The minimal focus on entrepreneurship in the school curriculum and the need to strengthen it was also articulated by administrators, teachers, parents, students, and local leaders during interviews and focus group interviews. For example:

Our Education system is not conducive to entrepreneurship. The approach to measuring students learning is, fundamentally exam based, assessment modes needs fundamental rethinking. The avenues to empower and motivate enterprising thoughts need to be integrated into education. Curriculum if redesigned, entrepreneurship can be infused into existing curriculum, not necessarily a discipline area (Principal 1). 
The above view was echoed by a teacher when he uttered "The idea of entrepreneurship is not embedded in the school subjects" (Teacher 1).

The above views were further substantiated when students in the focus group interviews expressed that: We have learnt few concepts both in primary and secondary education which are somewhat related to entrepreneurship. For example, in mathematics we learn about selling price, cost price, profit, income tax; in economics, we learn about market, organisation and financial institutions; in science about crop hybrid, which might be useful if some of us are thinking of being an entrepreneur in agriculture sector in the future; and in social studies we learn about means of transportation, climate and vegetation (Focus Group 2 \& Focus Group 3).

Some of the parents are also of the opinion that entrepreneurship concepts might be taken care of in higher classes; "In the school, we are not very sure about the entrepreneurship programme being offered, but may be in the higher classes as they study Economics" (Parent $2 \&$ Parent 3).

However, students communicated that what they have learnt in primary and secondary education is not enough to start their own business (Focus Group 1 and Focus Group 4). They feel that, one need to learn how to interact with people, which requires qualities like communication, patience, relation and confidence. The study carried out by the Ministry of Economic Affairs (MoEA, 2012) pointed the need to include enterprise education in school curriculum. The reason being the educational system is responsible for creating career aspirations amongst young people and has a duty to ensure that these are not mismatched with the realities of the job market that they face when leaving school. One of the measures they have put forward is to introduce entrepreneurial elements into parts of the national education curriculum, starting with subjects such as economics, commercial studies, accounting, socially useful and productive work and community services. In realising the measure put forward, they planned to work closely with the Ministry of Education.

Besides, including a specific topic of entrepreneurship in the syllabus, various study points to particular entrepreneurial qualities required to be a successful entrepreneur. Some of the entrepreneurial qualities necessary for an entrepreneur are: risk taker, relationship builder, promoter, knowledge seeker, independent, determination, delegator, creative thinker, confidence, business focus (McMullen \& Long, 1987; Rao, 2014; Vesper \& McMullan, 1988).

Subjects like English and Dzongkha would serve to develop communication skills as they focus on four strands: listening, speaking, reading and writing, which are important skills in entrepreneurship. Mathematics would lead to the development of basic numeracy skills. Concepts in mathematics such as probability would help in developing plans and decision making skills. Science which is studied from grade 4 onwards focuses on learning about living things, materials and phenomena through scientific method which includes observation, asking questions, hypothesizing, experimenting and drawing conclusions. However, all the above mentioned skills may not develop in relation to entrepreneurship, but purely in relation to the subject matters. It is, thus, concluded that the syllabi of the subjects in the 
school education have minimal entrepreneurship concepts and are not really aimed at awakening entrepreneurial spirit from an early age.

2) University Curriculum

The three colleges under Royal University of Bhutan, included under this study are Gaeddu College of Business Studies (GCBS), College of Science and Technology (CST) and Samtse College of Education (SCE). Entrepreneurship Development (ED) cell has been put in place in GCBS and CST and some of the initiatives undertaken by the cell are student's business incubation, awareness programs, and capacity development of faculty and students in GCBS and waste management, and GNH store in CST. In GCBS, the ED cell is fairly successful in achieving its targets. Currently, there are three small student business units at GCBS mentored by ED Cell. However, in CST, students' associate business and making money inferior to other jobs and are not keen to pursue it (Lecturer 1). This could be because it is an engineering college providing a degree level education and job opportunities both in government and private sector is considered to be higher for the student graduates of CST.

With respect to curriculum, GCBS offers Entrepreneurship Development Programme (EDP) as compulsory credited module to B.Com students and BBA EDP major. The curriculum has equal weighting on knowledge, skills and attitude components. Though curriculum is in place, one of the major challenges faced by GCBS is lack of interest from students. The teaching-learning process also needs fundamental rethinking to accommodate the demands of the entrepreneurship program (Lecturer 1). CST has developed the entrepreneurship curriculum and is offered to IT and Electronic Engineering students. The university wide generic entrepreneurship module has been used as a basis to adapt and offer a module to students. However, the major challenge in teaching entrepreneurship is changing the mindset of students, who already have made up their mind to seek employment (Lecturer 2).

In Samtse College of Education, the minimal concept of entrepreneurship is included in modules like commerce, economics and accountancy to Post Graduate Diploma in Education (PgDE) students. However, there is no separate curriculum committed to teaching entrepreneurship at any level of the Bachelor of Education (B. Ed) and PgDE programme. The need for teaching such curriculum was also not felt as almost all the student graduates from SCE were absorbed in government schools in Bhutan. Nevertheless, after the trained teacher intake drastically decreased in 2014, the college initiated to impart basic entrepreneurship skills to the final year B. Ed students in 2015 Spring Semester. It is a non-credited module and is offered as an optional module. In the beginning, it was offered as a compulsory non-credited module, but the response from the students was very weak. Hence it is offered as optional non-credited module in autumn 2015. Still the response from students is not encouraging. For example: In Autumn 2015, 40 students registered for the module, but at the end of the semester there were about 6-7 students only. In addition, these remaining students' attendance was also infrequent (discussion with Module tutor, 2015). Informal talk with B.Ed students revealed that their expectation to be employed in government service is still high despite a change in RCSC policy of teacher recriutment. 
When it comes to building of entrepreneurial qualities, the three colleges engage students in numerous curriculum activities (researching, presentation, group work, individual work, etc.) like in the schools. But as pointed out under school curriculum, these skills may develop purely in relation to the subject matters and not in relation to entrepreneurship.

\subsubsection{Pedagogy}

Entrepreneurship literature advocates the use of interactive and participatory teaching methods in teaching entrepreneurship skills. Wilson (2014) contends that entrepreneurship cannot be taught to students by lecturing them about what entrepreneurship is and what entrepreneurs do but through interactive and participatory teaching methods. It is well known that learning requires actual engagement. The curriculum documents, teacher's guide and education policies of Bhutan prescribe the use of child centered teaching methods to teach different subjects. Of late, teachers are trained on $21^{\text {st }}$ century teaching methods such as cooperative learning, activity based learning, inquiry learning and discovery learning. These methods lead to the development of skills such as creativity, problem solving, leadership, teamwork, decision making, positive interdependence and communication which are necessary for entrepreneurship (Kagan, 1989; Johnson, 1999). However, the development of these skills depends on how effectively and frequently teachers use these methods. Unfortunately, several studies in Bhutan have consistently shown that despite having emphasized on child-centered and interactive teaching, teacher-centered teaching continues to be the dominant teaching method used by teachers (Royal Education Council [REC], 2009; Keller \& Utha, 2014; Utha, 2015). For example, The REC (2009) reported the following:

- Teaching consists mostly of one-way talk by the teacher to convey textbook content without being able to get students to comprehend and demonstrate their learning.

- Grade room instruction shows predominance of a one-way talk by a teacher and writing on the chalkboard with lesser evidence of student-centric activities.

- $\quad$ There is little evidence of active dialogue between the students and teachers.

- In the class, students rarely ask questions and are not seen to be participating actively in the teaching process.

Sherab (2009) also claimed that teacher centered teaching is the dominant teaching method used by teachers in the primary schools in Bhutan. This kind of instruction has very limited prospects of developing an entrepreneurial culture in students (Hermann, Korunka, Luege, \& Mugler, 2005). This does not suggest that lecture style instruction is bad in itself; but it becomes a problem if it is the dominant mode of instruction delivery, excluding other methods such as skill building (i.e., group discussion, active case studies, brainstorming, research, etc.) or discovery (placement with entrepreneurs to learn hands-on experience, problem solving, solutions implementation, etc.) from the pedagogy (Wilson, 2014). 
In the colleges mentioned, the teaching - learning approach is a mixture of lecturing and participatory method. However, the dominant practice, especially in elective modules is lecturing (Lecturer, SCE, 2015).

The other activities that generate positive entrepreneurship culture in the schools and colleges are co-curricular activities.

\subsubsection{Co-Curricular Activities}

Co-curricular activities provide opportunities for students to engage in activities and develop entrepreneurial skills. The club is one of the important co-curricular activities in the schools and colleges. The survey shows that $68 \%$ of the respondents are engaged in one of the clubs listed in Table 4 . Table 4 reveals that the schools and colleges organise myriad of club activities, but most of these clubs do not adequately provide entrepreneurial experience to the students. Upon close analysis, most of these clubs can be categorised into social service clubs, music-oriented clubs, academic or career-related clubs, sports clubs and environment related clubs. Only a few clubs such as Barber Club, Arts and Craft club, Tarayana Club, Embroidery Club, Agriculture club and Home Science Club deals with entrepreneurial activities. Moreover, there are not many students who have participated in these clubs. For instance, only $5 \%$ of the student respondents are engaged in Tarayana club and the rest of the clubs such as barber club $(0.2 \%)$, arts and craft club (1.9\%), embroidery club $(0.2 \%)$, agriculture club $(1.4 \%)$ and home science $(0.3 \%)$ have less than $2 \%$.

The operation of few clubs promoting entrepreneurship and meager students participating in these clubs indicates that there is a minimal emphasis on this skill in the schools and colleges. This gives students minimal opportunity to develop an enterprising mindset and attitude.

Table 4. Clubs being Operated in Schools and Colleges

\begin{tabular}{|c|c|c|c|c|c|c|c|c|}
\hline Club & $\mathbf{N}$ & $\%$ & Club & $\mathbf{N}$ & $\%$ & Club & $\mathbf{N}$ & $\%$ \\
\hline Agriculture & 13 & 1.4 & Home science & 3 & 0.3 & Painting & 1 & 0.2 \\
\hline Archery & 5 & 0.8 & Games \& Sports & 63 & 10.4 & Radio & 1 & 0.2 \\
\hline and & & & Gross National & & & & & \\
\hline Crafts & 18 & 1.9 & Happiness & 3 & 0.5 & Reading & 7 & 1.2 \\
\hline \multirow{4}{*}{ Audio Visual } & & & & & & $\begin{array}{l}\text { Royal Society for } \\
\text { the Protection of }\end{array}$ & & \\
\hline & 1 & 0.2 & Health & 35 & 5.8 & Nature & 3 & 0.5 \\
\hline & & & Information & & & & & \\
\hline & & & Communication & & & & & \\
\hline Barber Club & 1 & 0.2 & Technology & 21 & 3.5 & Science & 34 & 5.6 \\
\hline Beautification & 3 & 0.5 & Indoor & 4 & 0.7 & Scout and culture & 20 & 3.3 \\
\hline Calligraphy & 1 & 0.2 & English Literature & 4 & 0.7 & Social Media & 11 & 1.8 \\
\hline
\end{tabular}




\begin{tabular}{lllllllll} 
Classical & & & & & & & & \\
Indian Dance & 1 & 0.2 & Knitting & 5 & 0.8 & Social Service & 2 & 0.3 \\
Counseling & 1 & 0.2 & Law & 7 & 1.2 & Photography & 19 & 3.1 \\
Cricket & 5 & 0.8 & Library & 22 & 3.6 & Tarayana & 31 & 5.1 \\
Cultural & 22 & 3.6 & Literary & 21 & 3.5 & Embroidery & 1 & 0.2 \\
Current & & & & & & Universal Human & & \\
Affairs & 10 & 1.7 & Maths & 11 & 1.8 & Values & 4 & 0.7 \\
Democracy & 32 & 5.3 & Media & 13 & 2.1 & Vocational Club & 6 & 1.0 \\
Drawing & 1 & 0.2 & Meditation & 5 & 0.8 & Voluntary club & 1 & 0.2 \\
Driglam & & & & & & & & \\
Namzha & 7 & 1.2 & Music & 17 & 2.8 & Waste Management & 1 & 0.2 \\
Electrical & & & & & & & & \\
Club & 3 & 0.5 & Nature & 29 & 4.8 & Writing Club & 1 & 0.2 \\
Dzongkha & 12 & 2.0 & Yoga & 5 & 0.8 & & & \\
\hline
\end{tabular}

During interviews, school principals, teachers, college lecturers, students and parents used various expressions to communicate their experiences with entrepreneurship related activities in the schools and colleges. Principal 1 claimed that:

To provide avenues for students to learn, vocational skills (electrical), arts classes and scouting events are organised... A number of teachers in my school have taken personal initiatives and invested in agro based ventures (Personal Interview).

Similarly, GCBS had also initiated Entrepreneurship Development (ED) cell in 2011. Some of the initiatives of the cell include student business incubation, awareness programmes, and capacity development of faculty members and students. Currently, there are three small student business units mentored by ED Cell (Lecturer 1, Personal Interview).

The above views were also echoed by Parent 3 when she referred specifically to the usefulness of the clubs like home science and arts and craft club, as discussed below:

Through Home Science club, they learn to cook different dishes on their own, whereas in arts and craft club, they learn to make beautiful arts and wood carvings of different shapes and beautiful structures and then sell it to raise funds for the school. Recently, we had a club exhibition and with no doubt these two clubs managed to earn a great deal of money. Not only this, during the school concert selling of variety show tickets helps them develop some skills of entrepreneurship.

We even have a vocational club where they learn to repair fans, tube lights and electrical appliances and electronics too. In our school such things are repaired by vocational club members without requiring to call other professionals thereby save money. And regarding personal initiative, the students who are very much interested in such things learn it during club hours and they always come up with initiatives without any need of teachers to tell them (Parent 3, Personal Interview).

Published by SCHOLINK INC 
The third activity that promotes entrepreneurship skills in students is through lecturer and teacher encouragement.

\subsubsection{Lecturer/Teacher Encouragement}

The survey report reveals that a majority (76\%) of lecturers and teachers encourage students to be innovative and creative and $67 \%$ lecturers and teachers encourage students to participate in activities that generate income. The interview data also ascertains that lecturers and teachers discuss entrepreneurship with students in varying settings both formal and informal. For example, Principal 1 asserts that "formal gathering such as assembly and casual gatherings enable faculty members and students to exchange ideas and pursue accordingly".

At CST, entrepreneurship and enterprise opportunities are discussed frequently by guest speakers, faculty and staff in informal settings by sharing success stories, drawing inspirations and ideas from others to students (Lecturer 2).

Similarly, avenues like fete day, cultural shows and sports activities are also used to encourage students to partake in entrepreneurship activities as detailed below;

The leaders, faculty, staff and students of Gedu College frequently discuss about entrepreneurship and enterprise creation in a variety of settings. Both faculty and students are pretty open to the idea of setting up ventures. Events such as college fete day, sales contest and impetus, give platform for students to learn the traits of doing smart business as well as test their ideas (Lecturer 2).

By the same token, most students posit that their schools create space for students to build the entrepreneurial qualities articulated by Rao (2014), such as:

- Morning speeches, literary activities, school concert, class presentation help in developing self-confidence and communication skills;

- $\quad$ Project work, solving problems, class work, homework-leads to one being independent;

- Science exhibition, club exhibition, class competition, writing essay-leads to developing innovation;

- $\quad$ Sporting events, assist to develop a sense of competition;

- House captains, class monitor, group presentation, project work aids in developing planning skills;

- Extempore speech makes one to take risks;

- Group work increases social skills.

(Focus Group1, Focus Group 2, Focus Group 3 \& Focus Group 4).

\subsubsection{Multi Language}

The analysis of focus group interview transcripts reveals that most of the students feel that what they have learnt in primary and secondary education is not enough to start their own business. They feel that one need to learn how to interact with people, which requires qualities such as communication, patience, relation and confidence (Focus Group 3).

Their ability to converse in multi language will aid them in building confidence and executing business transactions. The qualitative data revealed that the majority of the student respondents could 
communicate in as many as five languages. For instance, a local leader shared that his children can communicate in English, Lhotsham (Note 3), Dzongkha, Hindi and Lepcha kha (Note 4) (Local Government 1). Similarly, Parent 2 ascertains that her daughters can communicate in five languages such as English, Dzongkha, Sharshop, Lotsham and Hindi. The above views were also shared by students and teachers (Focus Group $2 \& 3$, Teacher 1).

\section{References}

Curriculum and Professional Support Division and Bhutan Board of Examination. (2010). Syllabus for Grade Nine and Ten. Thimphu: Ministry of Education.

Curriculum and Professional Support Division and Bhutan Board of Examination. (2012). Syllabus for Grades Eleven and Twelve. Thimphu: Ministry of Education.

Department of Curriculum Research and Development, Ministry of Education and Council for RNR Research of Bhutan. (2014). Agriculture for Food Security: A Textbook for Grade XI. Thimphu.

Druk Holding \& Investments Ltd. (2014). 5th BEGIN Training Program. Retrieved December 25, 2015, from http://www.dhi.bt/5th-begin

Entrepreneurship Education at School in Europe. (2012). Entrepreneurship Education at School in Europe: National Strategies, Curricula and Learning Outcomes. Education, Audiovisual and Culture Executive Agency.

Galloway, L., \& Brown, W. (2002). Entrepreneurship Education at University: A Driver in the Creation of High Growth Firms. Education and Training, 44, 398-408. http://dx.doi.org/10.1108/00400910210449231

Gibb, A. (2005). The Future of Entrepreneurship Education-Determining the Basis for Coherent Policy and Practice. Tampere: Research Centre for Vocational and Professional Education.

Global Entrepreneurship Research Association. (2013). Global Entrepreneurship Monitor 2012 Report. Retrieved December 15, 2015, from http://www.gemconsortium.org/docs/download/2645

Gross National Happiness Commission. (2013). Eleventh Five Year Plan Document. Thimphu: Gross National Happiness Commission, Royal Government of Bhutan.

Hermann, F., Korunka, C., Lueger, M., \& Mugler, J. (2005). Entrepreneurial Orientation and Education in Austrian Secondary Schools. Journal of Small Business and Enterprise Development, 12(2), 259-273. http://dx.doi.org/10.1108/14626000510594647

Hytti, U. (2002). State-of-Art of Enterprise Education in Europe. Turku: Entredu Project.

iDiscoveri Education and Royal Education Council. (2008). The Quality of School Education in Bhutan: Reality and Opportunities. Thimphu: REC.

Johnson, D. W., \& Jonshon, R. T. (1999). Cooperative Learning and Assessment. Retrieved December 8, 2015, from http://www.eric.ed.gov/PDFS/ED437852.pdf

Jones, C., \& English, J. (2004). A Contemporary Approach to Entrepreneurship Education. Emerald Group Publishing Limited. http://dx.doi.org/10.1108/00400910410569533 
Kagan, S. (1989). Cooperative Learning Resources for Teachers. San Juan Capistrano.

Karimi, S., Biemans, H., Lans, T., Mulder, M., \& Chizari, M. (2012). The Role of Entrepreneurship Education in Developing Students' Entrepreneurial Intentions. 10th Wageningen International Conference on Chain and Network Science 2012 (p. 22). Wageningen: Wageningen University.

Keller, H. D., \& Utha, K. (2014). Pedagogical Discourses in Bhutanese Upper Secondary School. Creative Economy. Creative University and Creative Development: Ideas, Knowledge and Paths.

Towards Sustainability, Happiness and Wellbeing. (n.d.). 3rd Creative University Conference, Royal University of Bhutan Convention Centre. Thimphu.

Kuratko, D. F., \& Hodgetts, R. M. (2004). Entreprenuership: Theory, Process, Practice. Mason: South-Western Publisher.

Kuratko, D. F. (2005). The Emergence of Entrepreneurship Education: Developments, Trends and Challenges. Baylor University Ministry of Economic Affairs. http://dx.doi.org/10.1111/j.1540-6520.2005.00099.x

Royal Government of Bhutan. (2012). Cottage, Small and Medium Industry Development Strategy 2012-2020 and Action Plan 2012-2014. Thimphu.

Ministry of Labour and Human Resources. (2010). National Human Resource Development Policy. Thimphu.

Ministry of Labour and Human Resources, Royal Government of Bhutan. (2014). 12th National LabourForce Survey. Thimphu.

Ministry of Labour and Human Resources, Royal Government of Bhutan and United Nations Development Program. (2014). Unemployed Youth Perception Survey. Thimphu.

Ministry of Labour and Human Resources, Royal Government of Bhutan. (2015). Labour Market Information Guide for Classes X and XII. Thimphu.

Ministry of Labour and Human Resources, Royal Government of Bhutan. (2015). Labour Market Information Guide for University Graduates. Thimphu.

Pittaway, L., \& Cope, J. (2006). Entrepreneurship Education: A systematic Review of the Evidence. National Council for Graduate entrepreneurship, working paper 2002/2006.

Rao, M. M. (2014). The 10 Qualities of a Successful Entrepreneur. Retrieved January 3, 2015, from http://mmm.yourstory.com/2014/12/10-qualities-successful-entrepreneur-strengths/

Rinchen, K. (2008). Education Reform in Bhutan: Meeting the Youth Employment Challenge. Retrieved January 3, 2015, from http://www.cipe.org

Rinchen, S. (2001). Bhutanese High School Girl's Perception of Science and the Impact of Science on Career Choice: Unpublished Thesis for the Master of Education Degree. University of New Brunswick, Frederiction, New Brunswick.

Royal Government of Bhutan. (2012). Cottage, Small and Medium Industry Policy of Bhutan. Thimphu. 
Royal Government of Bhutan. (2010). Economic Development Policy of Royal Government of Bhutan.

Thimphu.

Royal Monetary Authority of Bhutan. (2015). Annual Report 2014-2015. Thimphu.

Rubin, H., \& Rubin, I. (1995). Qualitative Interviewing: The Art of Hearing Data. Thousand Oaks, CA: Sage.

Shane, S., \& Venkataraman, S. (2000). The Promise of Entrepreneurship as a Field of Research.

$$
\text { Academy of Management Review, 217-226. }
$$

http://dx.doi.org/10.1111/j.1540-6520.2005.00099.x

Sherab, K. (2009). Bhutanese Teachers' Pedagogical Orientation in the Primary Grades (PP-VI): A Factor on Quality of Education. Retrieved December 5, 2015, from http://www.pce.edu.bt/cerd/Quality\%20of\%20Education\%20II.pdf

Tobgay, T. (2014). The State of The Tsa-Wa-Sum: Report to the Third Session of the Second Parliament of Bhutan. Thimphu.

Utha, K. (2015). Formative Assessment Practices in Bhutanese Secondary Schools and its Impact on Quality of Education: Doctoral Dissertation. Aalborg University: Aalborg, Denmark.

Wilson, J. M. (2014). Entrepreneurship Education Insights. Retrieved January 2, 2015, from http://www.jackmwilson.net/ArticlesTalks/EntrepreneurshipEducationInsights-16June2014.pdf

\section{Appendix A}

\section{Survey Questionnaire}

Fostering Entrepreneurship in Bhutan: Exploring Entrepreneurship Framework Conditions and Its Relationship to Economic Competitiveness in Bhutan, and Perception of Youth towards Entrepreneurship as a Career.

Dear Survey Respondent, The Royal University of Bhutan (RUB) in collaboration with the Business Opportunity and Information Centre (BOiC) is undertaking a research to explore the entrepreneurial culture and framework conditions and its relationship to economic competitiveness. The study also aims to explore perception towards entrepreneurship as a career option by the youths of Bhutan. You have been randomly selected for this survey and we would like to request you to kindly take some time in completing this survey. Your responses will remain CONFIDENTIAL.

\section{To be Filled in by the Enumerator}

\begin{tabular}{|l|l|}
\hline Form No. & \\
\hline Respondent No. & \\
\hline Place of Enumeration & \\
\hline District (Please refer the code book) & \\
\hline Respondent is selected as (Please refer the code book) & \\
\hline
\end{tabular}




\section{Only for School/College/Institute}

\begin{tabular}{|l|l|}
\hline Name (Please refer the code) & \\
\hline Level (Refer code book) & \\
\hline Location & \\
\hline Date of enumeration & \\
\hline
\end{tabular}

\section{Section A: Demographic Details}

\begin{tabular}{|c|c|}
\hline 1. Gender Male Female Other & \\
\hline \multicolumn{2}{|l|}{ 2. Age (in completed years) } \\
\hline \multirow[t]{3}{*}{ 3. The respondent is selected as: } & 1 School/College/TTI student \\
\hline & 2 Out of school youth \\
\hline & 3 Entrepreneurs \\
\hline \multirow[t]{8}{*}{ 4. Father's occupation } & 1 Own Busines \\
\hline & 2 Farmer \\
\hline & 3 Employed in private organization \\
\hline & 4 Corporate employee \\
\hline & 5 Civil servant \\
\hline & 6 Armed force (RBA/RBP/RBG) \\
\hline & 7 Home maker \\
\hline & 8 Others \\
\hline \multirow[t]{8}{*}{ 5. Mother's occupation } & 1 Own Business \\
\hline & 2 Farmer \\
\hline & 3 Employed in private organization \\
\hline & 4 Corporate employee \\
\hline & 5 Civil servant \\
\hline & 6 Armed force (RBA/RBP/RBG) \\
\hline & 7 Home maker \\
\hline & 8 Others \\
\hline \multirow{7}{*}{$\begin{array}{l}\text { 6. Educational attainment of parents with highest } \\
\text { education }\end{array}$} & 1 Bachelors degree or above \\
\hline & 2 Vocational Education including diploma) \\
\hline & 3 Class XII \\
\hline & 4 Class X \\
\hline & 5 Class PP to VIII \\
\hline & 6 Monk \\
\hline & 7 Non formal education \\
\hline
\end{tabular}




\begin{tabular}{|c|c|c|c|}
\hline & & \multicolumn{2}{|l|}{8 Others } \\
\hline \multirow{4}{*}{\multicolumn{2}{|c|}{ 7. Marital status }} & \multicolumn{2}{|l|}{1 Never married } \\
\hline & & \multicolumn{2}{|c|}{2 Married (including living together) } \\
\hline & & \multicolumn{2}{|c|}{3 Divorced (including separated ) } \\
\hline & & \multicolumn{2}{|c|}{$\begin{array}{l}4 \text { Widowed or widower (Only for } \\
\text { school/college/TTI Youths) }\end{array}$} \\
\hline \multicolumn{4}{|l|}{ 8. Name of the school/College/TTI } \\
\hline \multicolumn{4}{|l|}{ 9. Location } \\
\hline \multirow[t]{4}{*}{ 10. Level of institution } & & \multicolumn{2}{|c|}{ Level of institution } \\
\hline & & \multicolumn{2}{|c|}{2 Higher secondary } \\
\hline & & \multicolumn{2}{|c|}{3 College (Tertiary) } \\
\hline & & \multicolumn{2}{|c|}{4 Technical Training Institute } \\
\hline \multirow[t]{14}{*}{ 11. Class or programme } & \multicolumn{3}{|l|}{$1 X$} \\
\hline & \multirow{3}{*}{\multicolumn{2}{|c|}{$2 \mathrm{XII}$}} & a. Arts \\
\hline & & & b. Commerce \\
\hline & & & c. Science \\
\hline & \multirow{5}{*}{\multicolumn{2}{|c|}{$\begin{array}{l}3 \text { Certificate/Diploma or other } \\
\text { programmes }\end{array}$}} & a. Civil \\
\hline & & & b. Mechanical \\
\hline & & & c. Electrical \\
\hline & & & d. Zorig Chusum \\
\hline & & & e. Others \\
\hline & \multirow{5}{*}{\multicolumn{2}{|c|}{4 Bachelors }} & a. Arts \\
\hline & & & b. Commerce \\
\hline & & & c. Science \\
\hline & & & d. Engineering and Technology \\
\hline & & & e. Education \\
\hline \multirow{2}{*}{$\begin{array}{l}\text { 12. Are you a member of any } \\
\text { clubs in the school/college }\end{array}$} & \multicolumn{2}{|l|}{$1 \mathrm{Yes}$} & \\
\hline & \multicolumn{3}{|l|}{$2 \mathrm{No}$} \\
\hline \multicolumn{4}{|l|}{ 13. Name of the club } \\
\hline \multirow{4}{*}{$\begin{array}{l}\text { 14. What would you like to } \\
\text { pursue after graduation? }\end{array}$} & \multicolumn{2}{|c|}{1 Employment } & \\
\hline & \multicolumn{2}{|c|}{$\begin{array}{l}2 \text { Start an own business go to } \\
\text { Question No. } 16\end{array}$} & \\
\hline & \multicolumn{2}{|c|}{$\begin{array}{l}3 \text { Farming go to Question No. } \\
37\end{array}$} & \\
\hline & \multicolumn{2}{|l|}{4 Others } & \\
\hline
\end{tabular}




\begin{tabular}{|c|c|}
\hline \multirow{5}{*}{$\begin{array}{l}\text { 15. Preferred sector of } \\
\text { employment }\end{array}$} & 1 Government \\
\hline & 2 Corporation \\
\hline & 3 Private \\
\hline & 4 NGOs \\
\hline & 5 Others \\
\hline \multirow{3}{*}{$\begin{array}{l}\text { 16. What kind of business } \\
\text { would you like to start? }\end{array}$} & 1 Service \\
\hline & 2 Manufacturing \\
\hline & 3 Trading and intermediaries \\
\hline
\end{tabular}

\begin{tabular}{|c|c|c|}
\hline $\begin{array}{l}\text { (Only for entrepreneurs) } \\
17 . \text { Type of business }\end{array}$ & $\begin{array}{l}1 \\
2 \\
3 \\
4 \\
5 \\
6 \\
7\end{array}$ & $\begin{array}{l}\text { Agro and forest based } \\
\text { Manufacturing and Production } \\
\text { Trading and retail Hospitality and } \\
\text { tourism Contract } \\
\text { Services (consulting and other } \\
\text { services) Others }\end{array}$ \\
\hline 18. Year of establishment & $\begin{array}{l}2 \\
3 \\
4 \\
5\end{array}$ & $\begin{array}{l}2010 \\
2011 \\
2012 \\
2013 \\
2014 \\
2015\end{array}$ \\
\hline 19. Ownership type & $\begin{array}{l}2 \\
3 \\
4 \\
5\end{array}$ & $\begin{array}{l}\text { Sole proprietorship } \\
\text { Partnership Joint venture Family } \\
\text { business Others }\end{array}$ \\
\hline
\end{tabular}

\begin{tabular}{|c|c|}
\hline 20. Initial investment & \\
\hline \multirow{5}{*}{$\begin{array}{l}\text { 21. What were the sources of finance for the } \\
\text { establishment of your business }\end{array}$} & 1 Self go to Question No. 23 \\
\hline & 2 Family go to Question No. 23 \\
\hline & 3 Borrowings go to Question No. 22 \\
\hline & 4 equity go to Question No. 23 \\
\hline & 5 Others (specify) \\
\hline 22. Form which institution did you borrow & a. Bank of Bhutan \\
\hline
\end{tabular}




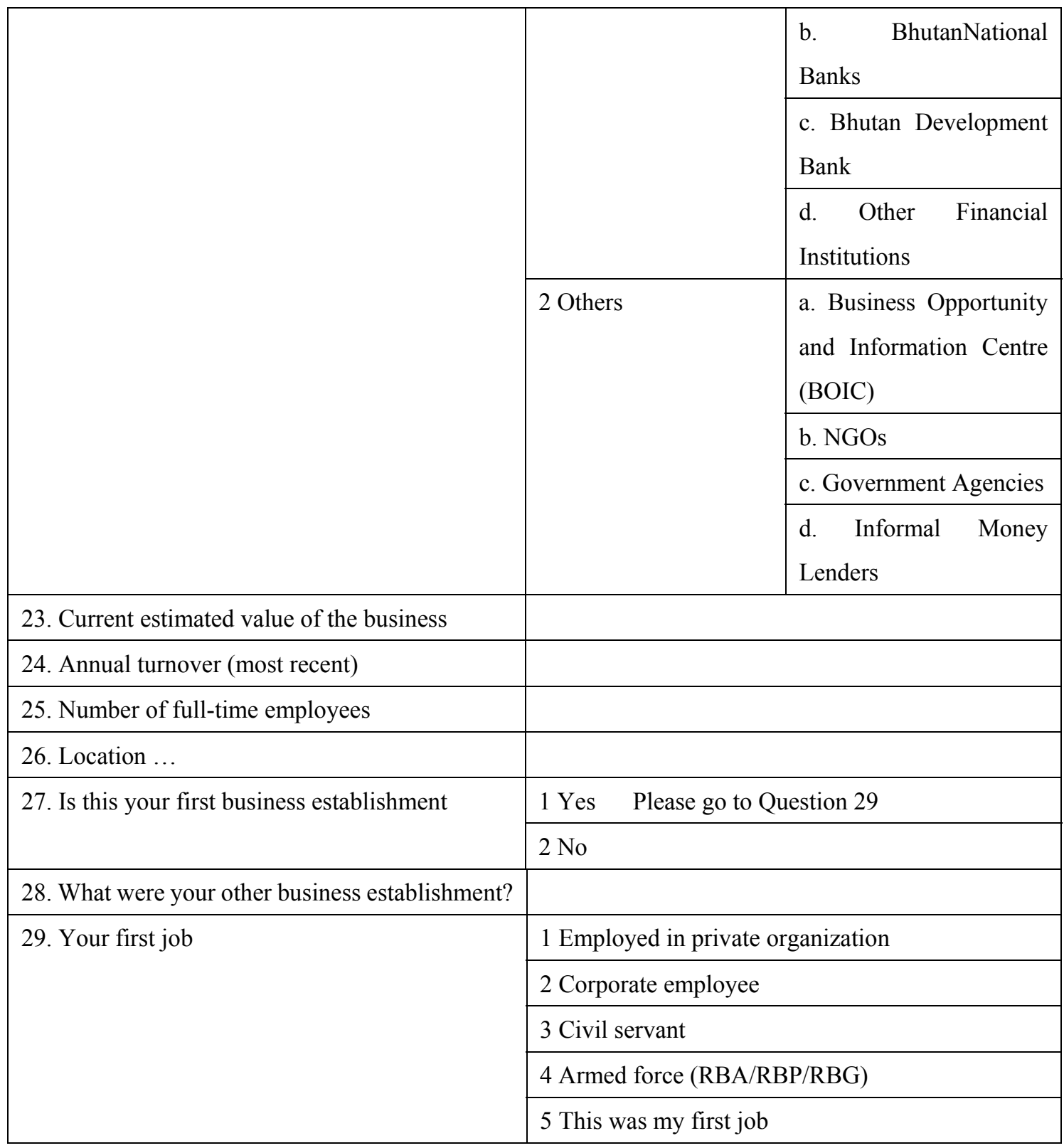

\section{Perception on Entrepreneurship Conditions}

Instructions

A number of items/statements about the Entrepreneurship Framework Conditions are provided in different sections of the questionnaire. The purpose is to gather information to understand current conditions and status of these framework conditions. Please read each item/statement carefully and respond to it by considering what you think of each statement. There are no CORRECT OR INCORRECT answers to any of the questions and we will not be assessing your knowledge and understanding of the concepts. Your responses will remain CONFIDENTIAL. Please feel free to share your frank opinion by indicating the degree to which you agree or disagree with each statement by CIRCLING the appropriate number. If you are not familiar with the concepts or are not sure of the 
current conditions, please feel free to CIRCLE the "Do Not Know" or the "Not Applicable" if it is not applicable to you. Your frank and honest opinion will help us in understanding the entrepreneurial framework conditions or the business environment and communicate the findings of the survey to policy makers, government and the implementing agencies.

You have 7 options to choose from. In this survey, $S D=$ Strongly Disagree, $\mathrm{D}=$ Disagree, $\mathrm{A}=$ Agree, $\mathrm{SA}=$ Strongly Agree, $\mathrm{N}=$ Neither Agree not Disagree, $\mathrm{DK}=$ Do not Know, and NA=Not Applicable.

\section{Section A: Social, Cultural Norms and Societal Support and Women Entrepreneurship}

\begin{tabular}{|c|c|c|c|c|c|c|c|c|}
\hline \multirow[t]{2}{*}{ S1. No } & \multirow[t]{2}{*}{ Particulars } & \multicolumn{7}{|c|}{ Level of agreement } \\
\hline & & SD & D & A & SA & $\mathrm{N}$ & DK & NA \\
\hline 37 & $\begin{array}{l}\text { Bhutanese culture emphasizes self-sufficiency, } \\
\text { autonomy, and personal initiative }\end{array}$ & 1 & 2 & 3 & 4 & 5 & 8 & 9 \\
\hline 38 & $\begin{array}{l}\text { Bhutanese culture encourages entrepreneurial } \\
\text { risk-taking }\end{array}$ & 1 & 2 & 3 & 4 & 5 & 8 & 9 \\
\hline 39 & $\begin{array}{l}\text { Bhutanese culture encourages creativity and } \\
\text { innovativeness }\end{array}$ & 1 & 2 & 3 & 4 & 5 & 8 & 9 \\
\hline 40 & $\begin{array}{l}\text { Bhutanese culture emphasizes that the individual is } \\
\text { responsible for managing his or her own life }\end{array}$ & 1 & 2 & 3 & 4 & 5 & 8 & 9 \\
\hline 41 & $\begin{array}{l}\text { The creation of new business is considered an } \\
\text { appropriate way to become rich }\end{array}$ & 1 & 2 & 3 & 4 & 5 & 8 & 9 \\
\hline 42 & $\begin{array}{l}\text { Most people consider becoming an entrepreneur as a } \\
\text { desirable career choice }\end{array}$ & 1 & 2 & 3 & 4 & 5 & 8 & 9 \\
\hline 43 & $\begin{array}{l}\text { Successful entrepreneurs have a high level of status } \\
\text { and respect }\end{array}$ & 1 & 2 & 3 & 4 & 5 & 8 & 9 \\
\hline 44 & $\begin{array}{l}\text { You will often see stories in the public media about } \\
\text { successful entrepreneurs }\end{array}$ & 1 & 2 & 3 & 4 & 5 & 8 & 9 \\
\hline 45 & $\begin{array}{l}\text { Most people think of entrepreneurs as competent, } \\
\text { resourceful individuals }\end{array}$ & 1 & 2 & 3 & 4 & 5 & 8 & 9 \\
\hline 46 & $\begin{array}{l}\text { There are sufficient social services available so that } \\
\text { women can continue to work even after they }\end{array}$ & 1 & 2 & 3 & 4 & 5 & 8 & 9 \\
\hline 47 & $\begin{array}{l}\text { Starting a new business is a socially acceptable career } \\
\text { option for women }\end{array}$ & 1 & 2 & 3 & 4 & 5 & 8 & 9 \\
\hline S1. No & Particulars & Ler & & re & nent & & & \\
\hline & & SD & & A & SA & $\mathrm{N}$ & DK & NA \\
\hline
\end{tabular}




\begin{tabular}{|c|c|c|c|c|c|c|c|c|}
\hline \multicolumn{3}{|c|}{$\begin{array}{l}\text { Women are encourag } \\
\text { start a new business }\end{array}$} & 2 & 3 & 4 & & 5 & 8 \\
\hline 49 & $\begin{array}{l}\text { Men and women get equally exposed to good } \\
\text { opportunities to start a new business }\end{array}$ & 1 & 2 & 3 & 4 & & 5 & 8 \\
\hline 50 & $\begin{array}{l}\text { Men and women have the same level of knowledge } \\
\text { and skills to start a new business }\end{array}$ & 1 & 2 & 3 & 4 & & 5 & 8 \\
\hline
\end{tabular}

Part B: Entrepreneurial Level in School and Colleges

\begin{tabular}{|c|c|c|c|c|c|c|c|c|}
\hline \multirow[t]{2}{*}{ Sl. No } & \multirow[t]{2}{*}{ Particulars } & \multicolumn{7}{|c|}{ Level of agreement } \\
\hline & & SD & D & A & SA & $\mathrm{N}$ & DK & NA \\
\hline 51 & $\begin{array}{l}\text { Primary and secondary education encourages } \\
\text { creativity, self-sufficiency, and personal initiative }\end{array}$ & 1 & 2 & 3 & 4 & 5 & 8 & 9 \\
\hline 52 & $\begin{array}{l}\text { Primary and secondary education provides adequate } \\
\text { instruction in market economic }\end{array}$ & 1 & 2 & 3 & 4 & 5 & 8 & 9 \\
\hline 53 & $\begin{array}{l}\text { Primary and secondary education provides adequate } \\
\text { attention to entrepreneurship and }\end{array}$ & 1 & 2 & 3 & 4 & 5 & 8 & 9 \\
\hline 54 & $\begin{array}{l}\text { Colleges provide good and adequate preparation for } \\
\text { starting up and growing new }\end{array}$ & 1 & 2 & 3 & 4 & 5 & 8 & 9 \\
\hline 55 & $\begin{array}{l}\text { The level of business and management education } \\
\text { provide good and adequate } \\
\text { preparation for starting up and growing new } 1\end{array}$ & & 2 & 3 & 4 & 5 & 8 & 9 \\
\hline 56 & $\begin{array}{l}\text { VTIs provide good and adequate preparation for } \\
\text { starting up and growing new businesses }\end{array}$ & 1 & 2 & 3 & 4 & 5 & 8 & 9 \\
\hline
\end{tabular}

\section{Part C: Physical Infrastructure and Professional Service Sccess}

\begin{tabular}{|c|c|c|c|c|c|c|c|c|}
\hline \multirow[t]{2}{*}{ Sl.No } & \multirow[t]{2}{*}{ Particulars } & \multicolumn{7}{|c|}{ Level of agreement } \\
\hline & & SD & D & A & SA & $\mathrm{N}$ & DK & NA \\
\hline 57 & $\begin{array}{l}\text { The physical infrastructure (roads, utilities, } \\
\text { communications, and waste disposal) } \\
\text { provides good support for new and growing } 1\end{array}$ & & 2 & 3 & 4 & 5 & 8 & 9 \\
\hline 58 & $\begin{array}{l}\text { it is expensive for a new or growing business to get } \\
\text { good access to }\end{array}$ & 1 & 2 & 3 & 4 & 5 & 8 & 9 \\
\hline 59 & $\begin{array}{l}\text { A new or growing business can get good access to } \\
\text { communications (telephone, internet, etc. ) in about a } 1 \\
\text { week }\end{array}$ & & 2 & 3 & 4 & 5 & 8 & 9 \\
\hline
\end{tabular}




\begin{tabular}{|c|c|c|c|c|c|c|c|c|}
\hline \multirow[t]{2}{*}{ SI.No } & \multirow[t]{2}{*}{ Particulars } & \multicolumn{7}{|c|}{ Level of agreement } \\
\hline & & SD & D & $\mathbf{A}$ & SA & $\mathbf{N}$ & DK & NA \\
\hline 60 & $\begin{array}{l}\text { New and growing business can afford the cost of } \\
\text { basic utilities (water, electricity, } \\
\text { fuel, sewerage) }\end{array}$ & 1 & 2 & 3 & 4 & 5 & 8 & 9 \\
\hline 61 & $\begin{array}{l}\text { New or growing business can get good access to } \\
\text { utilities (water, electricity, fuel, sewerages) in about a } \\
\text { month }\end{array}$ & & 2 & 3 & 4 & 5 & 8 & 9 \\
\hline 62 & $\begin{array}{l}\text { Bhutanese culture is supportive of individual success } \\
\text { achieved through own personal efforts. }\end{array}$ & s & 2 & 3 & 4 & 5 & 8 & 9 \\
\hline 63 & $\begin{array}{l}\text { There are enough subcontractors, suppliers, and } \\
\text { consultants to support new and growing businesses }\end{array}$ & d & 2 & 3 & 4 & 5 & 8 & 9 \\
\hline 64 & $\begin{array}{l}\text { New and growing business can afford the cost of } \\
\text { using subcontractors, suppliers, and Consultants }\end{array}$ & 1 & 2 & 3 & 4 & 5 & 8 & 9 \\
\hline 65 & $\begin{array}{l}\text { It is easy for new and growing business to get good } \\
\text { subcontractors, suppliers, and Consultants }\end{array}$ & d 1 & 2 & 3 & 4 & 5 & 8 & 9 \\
\hline 66 & $\begin{array}{l}\text { It is easy for new and growing business to get good } \\
\text { professional, legal, and accounting Services }\end{array}$ & 1 & 2 & 3 & 4 & 5 & 8 & 9 \\
\hline 67 & $\begin{array}{l}\text { It is easy for new and growing business to get good } \\
\text { banking services (checking accounts, foreign } \\
\text { exchange transactions, letters of credit, etc.) }\end{array}$ & d & 2 & 3 & 4 & 5 & 8 & 9 \\
\hline Sl.No & Particulars & Lev & of & rec & ment & & & \\
\hline & & SD & D & $\mathbf{A}$ & SA & $\mathbf{N}$ & DK & NA \\
\hline 68 & $\begin{array}{l}\text { There are good opportunities for creation of new } \\
\text { businesses }\end{array}$ & 1 & 2 & 3 & 4 & 5 & 8 & 9 \\
\hline 69 & $\begin{array}{l}\text { Number of good opportunities for the creation of new } \\
\text { business are more than the } \\
\text { number of people who are able to take advantage of }\end{array}$ & & 2 & 3 & 4 & 5 & 8 & 9 \\
\hline 70 & $\begin{array}{l}\text { Good opportunities for new business have } \\
\text { considerably increased in the past five }\end{array}$ & 1 & 2 & 3 & 4 & 5 & 8 & 9 \\
\hline 71 & Individuals can easily pursue business opportunities & 1 & 2 & 3 & 4 & 5 & 8 & 9 \\
\hline 72 & $\begin{array}{l}\text { Many people know how to start and manage a } \\
\text { high-growth business }\end{array}$ & & 2 & 3 & 4 & 5 & 8 & 9 \\
\hline
\end{tabular}




\begin{tabular}{|c|c|c|c|c|c|c|c|}
\hline 73 & $\begin{array}{l}\text { Many people know how to start and manage a small } \\
\text { business }\end{array}$ & 2 & 3 & 4 & 5 & 8 & 9 \\
\hline 74 & $\begin{array}{l}\text { Many people have experience in starting a new } 1 \\
\text { business }\end{array}$ & & 3 & 4 & 5 & 8 & 9 \\
\hline
\end{tabular}

\begin{tabular}{|c|c|c|c|c|c|c|c|c|}
\hline \multirow[t]{2}{*}{ SI.No } & \multirow[t]{2}{*}{ Particulars } & \multicolumn{7}{|c|}{ Level of agreement } \\
\hline & & SD & D & A & SA & $\mathbf{N}$ & DK & NA \\
\hline 75 & $\begin{array}{l}\text { Many people can react quickly to good business } \\
\text { opportunities }\end{array}$ & 1 & 2 & 3 & 4 & 5 & 8 & 9 \\
\hline 76 & $\begin{array}{l}\text { Many people have the ability to organize the } \\
\text { resources required for a new business }\end{array}$ & 1 & 2 & 3 & 4 & 5 & 8 & 9 \\
\hline
\end{tabular}

Part E: Government Policy, Support and Bureaucracy

\begin{tabular}{|c|c|c|c|c|c|c|c|c|}
\hline \multirow[t]{2}{*}{ SI.No } & \multirow[t]{2}{*}{ Particulars } & \multicolumn{7}{|c|}{ Level of agreement } \\
\hline & & SD & D & A & SA & $\mathbf{N}$ & DK & NA \\
\hline 77 & $\begin{array}{l}\text { Government policies on public procurement } \\
\text { consistently favor new business. }\end{array}$ & 1 & 2 & 3 & 4 & 5 & 8 & 9 \\
\hline 78 & $\begin{array}{l}\text { The support for new and growing business is a high } \\
\text { priority for the government. }\end{array}$ & 1 & 2 & 3 & 4 & 5 & 8 & 9 \\
\hline 79 & $\begin{array}{l}\text { The support for new and growing business is a high } \\
\text { priority for policy at the local government level }\end{array}$ & 1 & 2 & 3 & 4 & 5 & 8 & 9 \\
\hline 80 & $\begin{array}{l}\text { New business can get most of the required permits } \\
\text { and licenses in about a week. }\end{array}$ & 1 & 2 & 3 & 4 & 5 & 8 & 9 \\
\hline 81 & $\begin{array}{l}\text { The amount of taxes is a burden for new and } \\
\text { growing business. }\end{array}$ & 1 & 2 & 3 & 4 & 5 & 8 & 9 \\
\hline 82 & $\begin{array}{l}\text { Government regulations are applied to new and } \\
\text { growing business in a predictable and consistent way } 1\end{array}$ & & 2 & 3 & 4 & 5 & 8 & 9 \\
\hline 83 & $\begin{array}{l}\text { Coping with government bureaucracy, regulations, } \\
\text { and licensing requirements are difficult for new and } 1 \\
\text { growing businesses }\end{array}$ & & 2 & 3 & 4 & 5 & 8 & 9 \\
\hline 84 & $\begin{array}{l}\text { A wide range of government assistance for new and } \\
\text { growing business can be obtained through contact1 } \\
\text { with a single agency }\end{array}$ & & 2 & 3 & 4 & 5 & 8 & 9 \\
\hline 85 & Business incubators provide effective support for & & & & & & & \\
\hline
\end{tabular}




\begin{tabular}{|l|l|l|l|l|l|l|l|l|}
\hline & new and growing businesses & 1 & 2 & 3 & 4 & 5 & 8 & 9 \\
\hline 86 & $\begin{array}{l}\text { There are an adequate number of government } \\
\text { programs for new and growing businesses }\end{array}$ & 1 & 2 & 3 & 4 & 5 & 8 & 9 \\
\hline 87 & $\begin{array}{l}\text { Government employees working for business } \\
\text { promotion are competent and Effective in supporting } 1 \\
\text { new and growing businesses }\end{array}$ & 2 & 3 & 4 & 5 & 8 & 9 \\
\hline 88 & $\begin{array}{l}\text { Government programs aimed at supporting new and } \\
\text { growing business are effective }\end{array}$ & & 2 & 3 & 4 & 5 & 8 & 9 \\
\hline 89 & $\begin{array}{l}\text { There are many support initiatives that are specially } \\
\text { tailored for high-growth entrepreneurial activity }\end{array}$ & 1 & 2 & 3 & 4 & 5 & 8 & 9 \\
\hline 90 & $\begin{array}{l}\text { Policy-makers are aware of the importance of } \\
\text { high-growth entrepreneurial activity }\end{array}$ & & & & & & & \\
\hline
\end{tabular}

\begin{tabular}{|c|c|c|c|c|c|c|c|c|}
\hline \multirow[t]{2}{*}{ Sl.No } & \multirow[t]{2}{*}{ Particulars } & \multicolumn{7}{|c|}{ Level of agreement } \\
\hline & & SD & D & A & SA & $\mathbf{N}$ & DK & NA \\
\hline 91 & $\begin{array}{l}\text { People working in entrepreneurship support } \\
\text { initiatives are competent to support high-growth } 1 \\
\text { businesses }\end{array}$ & & 2 & 3 & 4 & 5 & 8 & 9 \\
\hline 92 & $\begin{array}{l}\text { Potential for rapid growth is often used as a selection } \\
\text { criterion when choosing recipients of } 1 \\
\text { entrepreneurship support }\end{array}$ & & 2 & 3 & 4 & 5 & 8 & 9 \\
\hline 93 & $\begin{array}{l}\text { Government programs are highly selective when } \\
\text { choosing recipients of entrepreneurship support }\end{array}$ & 1 & 2 & 3 & 4 & 5 & 8 & 9 \\
\hline
\end{tabular}

Part F: Internal Market Dynamics and Cooperative Services

\begin{tabular}{|c|c|c|c|c|c|c|c|c|}
\hline \multirow[t]{2}{*}{ Sl.No } & \multirow[t]{2}{*}{ Particulars } & \multicolumn{7}{|c|}{ Level of agreement } \\
\hline & & SD & D & A & SA & $\mathbf{N}$ & DK & NA \\
\hline 94 & $\begin{array}{l}\text { The markets for consumer goods and services } \\
\text { change dramatically from year to year }\end{array}$ & s & 2 & 3 & 4 & 5 & 8 & 9 \\
\hline 95 & $\begin{array}{l}\text { The markets for business -to-business goods and } \\
\text { services change dramatically from year to Year }\end{array}$ & 1 & 2 & 3 & 4 & 5 & 8 & 9 \\
\hline 6 & $\begin{array}{l}\text { New and growing business can easily enter new } \\
\text { markets }\end{array}$ & 1 & 2 & 3 & 4 & 5 & 8 & 9 \\
\hline 97 & $\begin{array}{l}\text { The new and growing business can afford the cost of } \\
\text { market entry }\end{array}$ & 1 & 2 & 3 & 4 & 5 & 8 & 9 \\
\hline 98 & New and growing business can enter markets & & & & & & & \\
\hline
\end{tabular}




\begin{tabular}{|c|c|c|c|c|c|c|c|c|}
\hline & $\begin{array}{l}\text { without being unfairly blocked by established } \\
\text { Businesses }\end{array}$ & 1 & 2 & 3 & 4 & 5 & 8 & 9 \\
\hline 99 & $\begin{array}{l}\text { Anti-trust legislation is effective and well enforced } \\
\text { (anti-trust: anti-monopoly) }\end{array}$ & 1 & 2 & 3 & 4 & 5 & 8 & 9 \\
\hline 100 & $\begin{array}{l}\text { There are no formal restrictions if you want to start a } \\
\text { business using the Resources, knowledge and } \\
\text { contacts obtained from your current job as an } 1 \\
\text { employee }\end{array}$ & & 2 & 3 & 4 & 5 & 8 & 9 \\
\hline 101 & $\begin{array}{l}\text { Top-down decision making strategies dominate } \\
\text { bottom-up decision making strategies within large } 1 \\
\text { organizations }\end{array}$ & & 2 & 3 & 4 & 5 & 8 & 9 \\
\hline 102 & $\begin{array}{l}\text { Top-down decision making strategies dominate } \\
\text { bottom-up decision making strategies within small } 1 \\
\text { and medium sized organizations }\end{array}$ & & 2 & 3 & 4 & 5 & 8 & 9 \\
\hline 103 & $\begin{array}{l}\text { Employers provide support to employees who come } \\
\text { up with new ideas }\end{array}$ & 1 & 2 & 3 & 4 & 5 & 8 & 9 \\
\hline 104 & $\begin{array}{l}\text { Employees support colleagues who come up with } \\
\text { new ideas }\end{array}$ & 1 & 2 & 3 & 4 & 5 & 8 & 9 \\
\hline
\end{tabular}

Part G: Research \& Development Transfer, Intellectual Property Rights and Valuation of Innovation

\begin{tabular}{|c|c|c|c|c|c|c|c|c|}
\hline \multirow[t]{2}{*}{ Sl.No } & \multirow[t]{2}{*}{ Particulars } & \multicolumn{7}{|c|}{ Level of agreement } \\
\hline & & SD & D & A & SA & $\mathbf{N}$ & DK & NA \\
\hline 105 & $\begin{array}{l}\text { Businesses like to experiment with new technologies } \\
\text { and with new ways of doing things }\end{array}$ & 1 & 2 & 3 & 4 & 5 & 8 & 9 \\
\hline 106 & Consumers like to try out new products and services & 1 & 2 & 3 & 4 & 5 & 8 & 9 \\
\hline 107 & Innovation is highly valued by businesses & 1 & 2 & 3 & 4 & 5 & 8 & 9 \\
\hline 108 & Innovation is highly valued by consumers & 1 & 2 & 3 & 4 & 5 & 8 & 9 \\
\hline 109 & $\begin{array}{l}\text { Established businesses are open to using new, } \\
\text { entrepreneurial businesses as suppliers }\end{array}$ & 1 & 2 & 3 & 4 & 5 & 8 & 9 \\
\hline 110 & $\begin{array}{l}\text { Consumers are open to buying products and services } \\
\text { from new, entrepreneurial businesses }\end{array}$ & 1 & 2 & 3 & 4 & 5 & 8 & 9 \\
\hline 111 & $\begin{array}{l}\text { New technology and other knowledge are } \\
\text { transferred from universities and research } \\
\text { centers to new and growing businesses }\end{array}$ & 1 & 2 & 3 & 4 & 5 & 8 & 9 \\
\hline
\end{tabular}




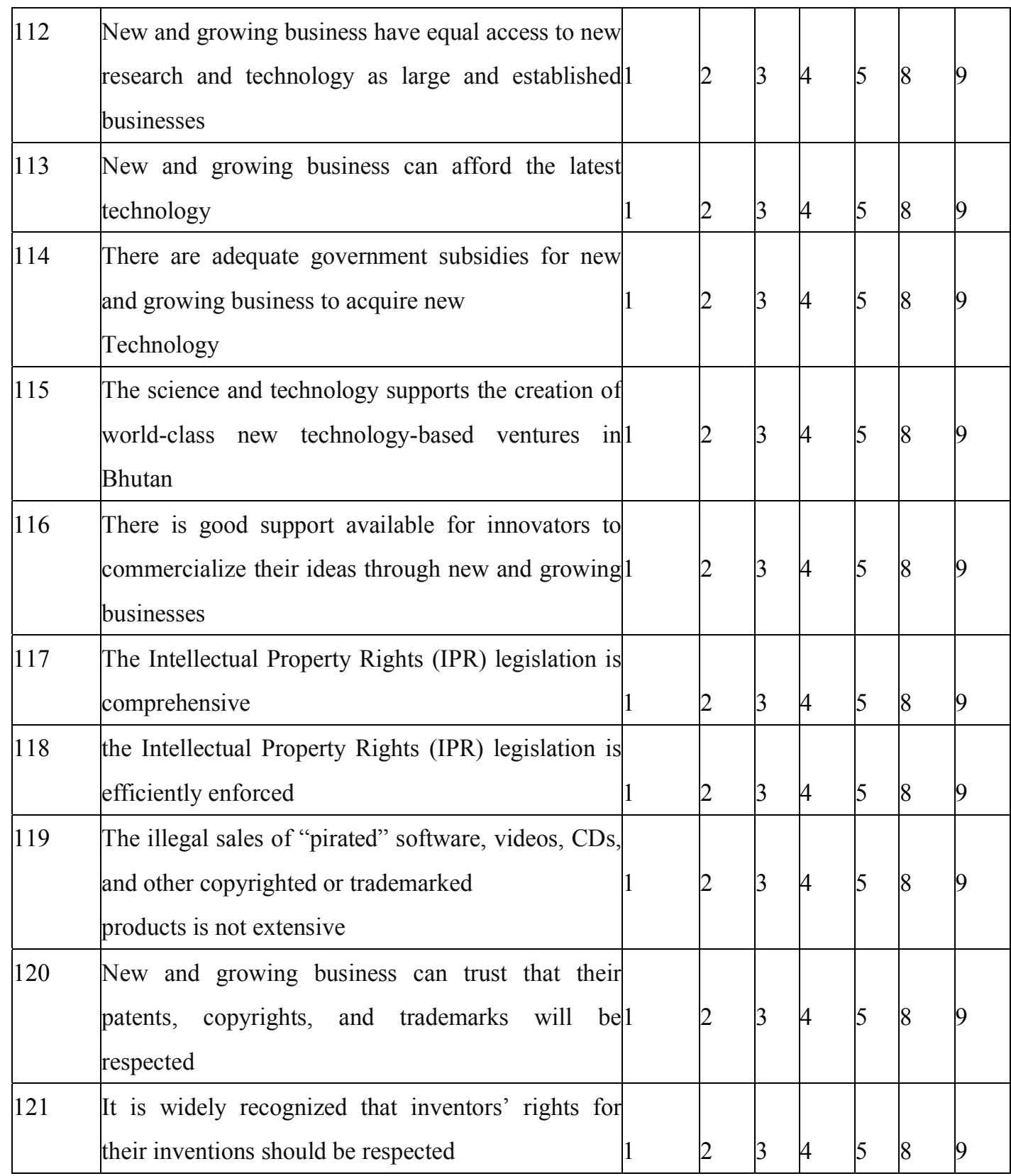

Part H: Financial Environment and Determinants of Intrapreneurship Activity

\begin{tabular}{|c|c|c|c|c|c|c|c|c|}
\hline \multirow[t]{2}{*}{ SI.No } & \multirow[t]{2}{*}{ Particulars } & \multicolumn{7}{|c|}{ Level of agreement } \\
\hline & & SD & D & $\mathbf{A}$ & SA & $\mathbf{N}$ & DK & NA \\
\hline 122 & $\begin{array}{l}\text { There is sufficient funding available for new and } \\
\text { growing business }\end{array}$ & d 1 & 2 & 3 & 4 & 5 & 8 & 9 \\
\hline 123 & $\begin{array}{l}\text { The government support development of new and } \\
\text { growing business through financial subsidy such as } \\
\text { "low interest rate or interest free" loans, or collateral }\end{array}$ & & 2 & 3 & 4 & 5 & 8 & 9 \\
\hline
\end{tabular}




\begin{tabular}{|l|l|l|l|l|l|l|l|}
\hline & free loans & & & & & & \\
\hline 124 & $\begin{array}{l}\text { There is sufficient venture capitalist funding } \\
\text { available for new and growing business. [by } \\
\text { venture capital we mean institutions or individuals }\end{array}$ & 2 & 3 & 4 & 5 & 8 & 9 \\
\hline $\begin{array}{l}\text { who fund a new business for a return] } \\
125\end{array}$ & $\begin{array}{l}\text { There is sufficient funding available through initial } \\
\text { public offerings (IPOs) for new and growing } \\
\text { business [by IPOs, we mean raising money from the } \\
\text { public by selling shares orownership of the }\end{array}$ & 2 & 3 & 4 & 5 & 8 & 9 \\
\hline 126 & $\begin{array}{l}\text { business] } \\
\text { Entrepreneurs have much less access to social } \\
\text { security [such as provident fund, pension, gratuity] } \\
\text { than employees }\end{array}$ & 2 & 3 & 4 & 5 & 8 & 9 \\
\hline 127 & $\begin{array}{l}\text { The level of employment protection is deterring } \\
\text { employees to start their own business }\end{array}$ & 1 & 2 & 3 & 4 & 5 & 9 \\
\hline
\end{tabular}

Section I: Only for Students

\begin{tabular}{|c|c|c|c|c|c|c|c|c|}
\hline \multirow[t]{2}{*}{ Sl.No } & \multirow[t]{2}{*}{ Particulars } & \multicolumn{7}{|c|}{ Level of agreement } \\
\hline & & SD & D & $\mathbf{A}$ & SA & $\mathbf{N}$ & DK & NA \\
\hline 128 & $\begin{array}{l}\text { I am interested in starting my own business in } \\
\text { future. }\end{array}$ & 1 & 2 & 3 & 4 & 5 & 8 & 9 \\
\hline 129 & I have business plans and ideas to pursue in future & 1 & 2 & 3 & 4 & 5 & 8 & 9 \\
\hline 130 & I know the process to start business & 1 & 2 & 3 & 4 & 5 & 8 & 9 \\
\hline 131 & I would prefer a regular job with a steady income & 1 & 2 & 3 & 4 & 5 & 8 & 9 \\
\hline 132 & $\begin{array}{l}\text { During holidays (summer or winter break), I help } \\
\text { my parents/relatives/friends to run their business. }\end{array}$ & 1 & 2 & 3 & 4 & 5 & 8 & 9 \\
\hline 133 & My family talks business plans and ideas & 1 & 2 & 3 & 4 & 5 & 8 & 9 \\
\hline 134 & $\begin{array}{l}\text { I discuss and propose business plans and ideas to my } \\
\text { family }\end{array}$ & 1 & 2 & 3 & 4 & 5 & 8 & 9 \\
\hline 135 & I discuss business plans and ideas with my relatives & 1 & 2 & 3 & 4 & 5 & 8 & 9 \\
\hline
\end{tabular}

\begin{tabular}{|l|l|l|l|l|l|l|l|l|}
\hline SI.No & Particulars & \multicolumn{9}{|l|}{ Level of agreement } \\
\cline { 4 - 10 } & & SD & D & A & SA & N & DK & NA \\
\hline 136 & $\begin{array}{l}\text { My parents want me to take care of their business in } \\
\text { future }\end{array}$ & 2 & 3 & 4 & 5 & 8 & 9 \\
\hline
\end{tabular}




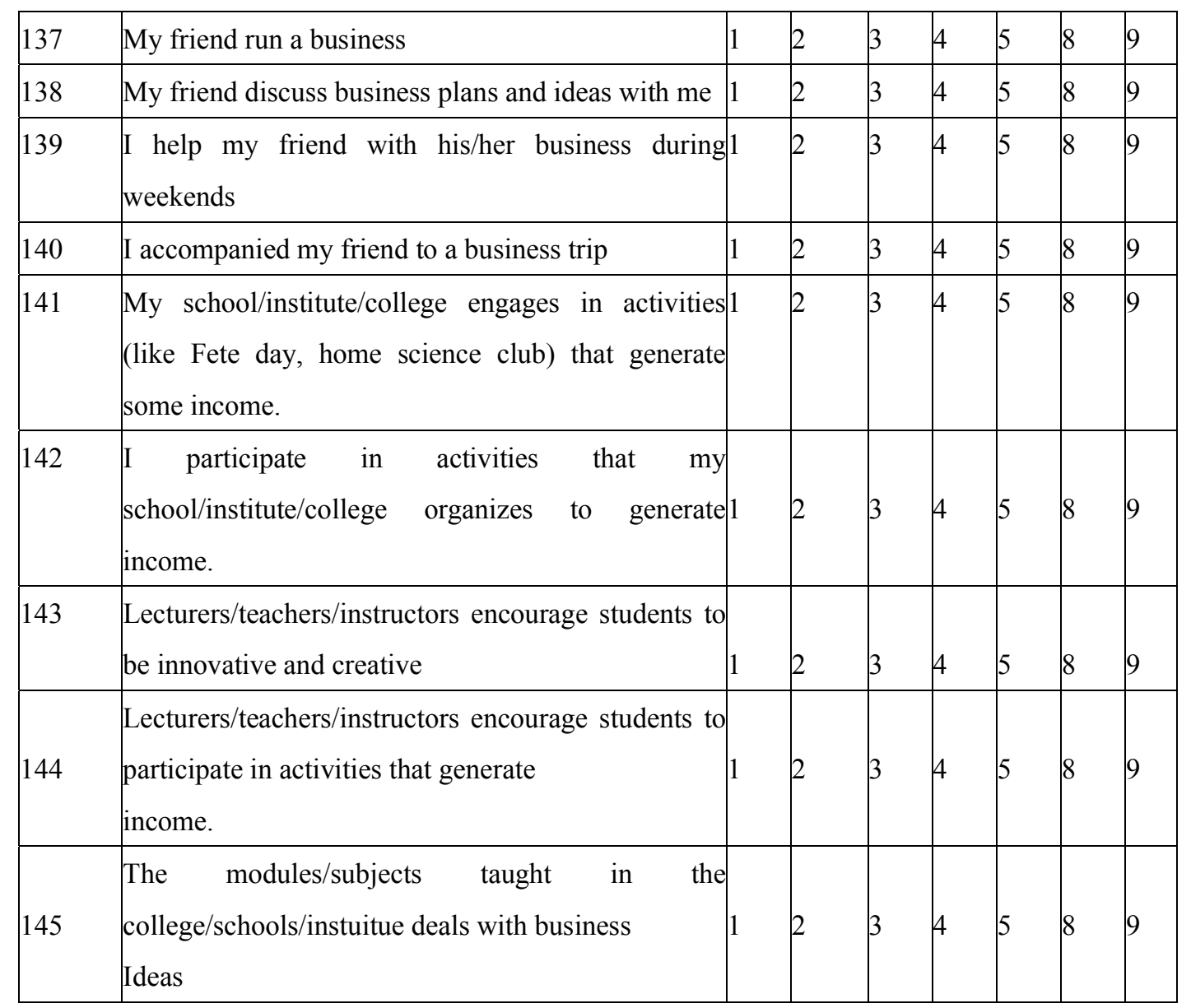

\section{Section J: Only for Entrepreneurs}

\begin{tabular}{|c|c|}
\hline \multirow{5}{*}{$\begin{array}{l}\text { 146. Why did you choose to become an } \\
\text { entrepreneur? }\end{array}$} & Self-reliance \\
\hline & Prestige \\
\hline & Family/peer support \\
\hline & Couldn't get any other job \\
\hline & Any others \\
\hline \multirow{7}{*}{$\begin{array}{l}\text { 147. Who supported you in developing business } \\
\text { idea }\end{array}$} & Mentor/Teachers \\
\hline & Family members \\
\hline & Spouse \\
\hline & Friends \\
\hline & Government \\
\hline & $\mathrm{NGO}$ \\
\hline & Other \\
\hline \multirow[t]{3}{*}{ 148. Who supported you in accessing finance } & 1 Mentors/Teachers \\
\hline & 2 Family members \\
\hline & 3 Spouse \\
\hline
\end{tabular}




\begin{tabular}{|c|c|}
\hline & 4 Friends \\
\hline & 5 Government \\
\hline & ${ }_{6} \mathrm{NGO}$ \\
\hline & ${ }_{7}$ Other \\
\hline \multirow{2}{*}{$\begin{array}{l}\text { 149. If you were offered a job, would you accept } \\
\text { it: }\end{array}$} & $1 \mathrm{Yes}$ \\
\hline & $2 \mathrm{No}$ \\
\hline \multirow{5}{*}{$\begin{array}{l}\text { 150. Which is your preferred sector of } \\
\text { employment? }\end{array}$} & 1 Government \\
\hline & 2 Corporation \\
\hline & 3 Private \\
\hline & 4 NGOs \\
\hline & 5Others \\
\hline
\end{tabular}

\section{Section K: Training Need Assessment (Only for Entrepreneurs)}

151. Did you attend any entrepreneurial or business management trainings supported by the government or other agencies in last three years? (Yes/NoYesNoGotoQ.

\begin{tabular}{|l|l|l|l|}
\hline Year & Training programme & Duration & Sponsor \\
\hline & & & \\
\hline & & & \\
\hline & & & \\
\hline
\end{tabular}

152. On a scale of $\mathbf{0}$ to $\mathbf{1 0}$, how would you rate your knowledge and skills in the following business management areas? "0" means you do not know anything and "10" means excellent knowledge and skills.

Rating (0 to 10 )

\begin{tabular}{|c|c|c|}
\hline 1 & Business planning & ..... \\
\hline 2 & Financial management & $\ldots \ldots$ \\
\hline 3 & Performance management & ...... \\
\hline 4 & Human Resource Management & $\ldots$ \\
\hline 5 & Marketing & . $\ldots \ldots \ldots \ldots \ldots \ldots \ldots$ \\
\hline 6 & Book keeping & .... \\
\hline 7 & Growth management & \\
\hline 8 & Product development & $\ldots$ \\
\hline 9 & Business Compliance & \\
\hline
\end{tabular}


153. On a scale of $\mathbf{0}$ to 10, in your opinion, which among the following areas of training will be important for your business growth and expansion? "0" means not important and "10" means most important.

Rating (0 to 10$)$

\begin{tabular}{|c|c|c|}
\hline 1 & Business planning & \\
\hline 2 & Financial management & \\
\hline 3 & Performance management & \\
\hline 4 & Human Resource Management & \\
\hline 5 & Marketing & \\
\hline 6 & Book keeping & \\
\hline
\end{tabular}

154. When you encounter problems with business management, from whom do you seek support?

1 My teachers/mentors

2 Family members

4 Friends

${ }_{5}$ Other business persons

${ }_{6}$ Consulting firms

Others

Section E: General perception

\begin{tabular}{|l|c|l|}
\hline $\begin{array}{l}\text { 155. What is your view on cause of } \\
\text { unemployment }\end{array}$ & $\begin{array}{l}1 \\
\text { situation in Bhutan? }\end{array}$ & $\begin{array}{l}\text { Mismatch of skills and demand } \\
\text { No enough job }\end{array}$ \\
\hline & 4 & Yack of experience \\
\hline & 5 & Youth are not willing to take up entrepreneurship \\
\hline 156. What do you think are & 1 & Lack skills \\
\hline the reasons for youths & 2 & Lack finance \\
\hline not willing to take up & 3 & Not willing to take risk \\
\hline entrepreneurship & 4 & Lack of social/family support \\
\hline
\end{tabular}

157. Why do you think youth are not interested to work

1 Low salary

-2 Lack of benefit

-3 Poor work culture and environment

-4 Location 
5 Others

158 Which in your opinion are the three most constraining factor of developing Ratings entrepreneurship in Bhutan at the moment. Please rate the three most constraining factor in order.

$1 \quad$ Financial support

$2 \quad$ Government policies

3 Government programs

$4 \quad$ Education and training

\begin{tabular}{l|l}
5 & R\&D transfer
\end{tabular}

6 Commercial and professional infrastructure

$7 \quad$ Market Openness

$8 \quad$ Access to physical infrastructure

$9 \quad$ Cultural and social norms

10 Capacity for entrepreneurship

11 Economic climate

12 Work force features

13 Perceived population composition

14 Political, institutional and social context

159 Which in your opinion are the three most important factor to developing entrepreneurship in Bhutan at the moment. Please rate the three most enambling Ratings factor in order.

$1 \quad$ Financial support

$2 \quad$ Government policies

$3 \quad$ Government programs

$4 \quad$ Education and training

$5 \quad$ R\&D transfer

6 Commercial and professional infrastructure

$7 \quad$ Market Openness

8 Access to physical infrastructure

$9 \quad$ Cultural and social norms

10 Capacity for entrepreneurship

11 Economic climate

12 Work force features

13 Perceived population composition

Published by SCHOLINK INC. 
$14 \quad$ Political, institutional and social context

\section{Any other}

Assessment by enumerator

158. Was this self-enumerated Yes No

159. Were other present during the enumeration Yes No

160. Was the respondent interrupted by other during the enumeration (interruption will also include telephone calls) Yes No

161. Overall assessment of the enumeration on the information

Very Good Good Not Good

162. Comments:

163. Name of the Enumerator

164. Name of the supervisor

\section{APPENDIX B}

\section{SEMI STRUCTURE INTERVIEW PROTOCOL}

1. What is your perception on entrepreneurship?

2. Why do you think it is good to start a business?

3. What would you like your children to pursue after his/her studies?

4. As a parent would you encourage your children to take up entrepreneurship as a career?

5. You have been in the school for sometime as a teacher and your children go to school So do you think students in Bhutanese schools have enough ideas about entrepreneurship?

6. Do you think your children are interested in taking entrepreneurship as a career?

Why do you say so?

7. Do you think business skills should be taught in the schools?

8. Do you think the present school curriculum include activities that create creativity, encourage sufficiency and personal initiatives?

9. Can you suggest some activities which can be carried out in the school to foster business ideas to the students?

10. Does your children participate in co-curricular activities?

11. Do you and your family members allow your children to do their school work independently? Why?

12. Does your child help you in the household activities?

13. In how many languages can your children communicate? How proficient are they in these languages?

14. Does your children complete tasks give by you to them on time?

15. Do you and your relatives give pocket money to your children?

16. What do they do with the pocket money? 
17. Does your children have the habit of saving money?

18. Does your children discuss about business plans and activities at home?

19. Has anyone in your family become a successful business person before?

20. Are you aware of any government policies that encourage or favor entrepreneurship in the country?

21. Do you think there is effective government program that aim at supporting new and growing business?

22. Do you think the support for new and growing business should be a top priority in the country?

23. Do you think there are sufficient government subsidies for new and growing business?

24. In your opinion what needs to be done to foster business in the country?

\section{APPENDIX C}

\section{FOCUS GROUP INTERVIEW-PROTOCOL}

\section{A. Perceptions/career options}

i. What is your ambition? Why?

ii. What is your perception on entrepreneurship (starting business)? Highlight its importance

iii. Have you thought of taking up entrepreneurship as a career after completing your studies? Why?

iv. Will entrepreneurship knowledge if provided in schools, empower you to face the challenges of unemployment?

\section{B. Syllabus/curriculum/co-curricular activities}

i. Does primary school curriculum (school text, pedagogy) include activities that encourage creativity, sufficiency and personal initiative?

ii. Does curriculum in secondary education provide adequate attention to entrepreneurship and business creation?

iii. What co-curricular activities does your school organize?

iv. What co-curricular activities do you participate in? Why?

\section{Entrepreneurship educational framework conditions}

i. Do your teachers allow you to work independently? How often?

ii. Do you like to work independently? Why?

iii. Do you like to work with friends? Why?

iv. With how many languages you communicate with? (ask about the degree of proficiency in all the languages)

v. Do you complete the task assigned to you on time? How often?

vi. Do you manage your time efficiently? (Ask about a typical daily routine)

vii. Have you done any community service as a student?

viii. Do your parents/relatives give you some pocket money? What do you do with it?

ix. Do you save the money that you get from parents or relatives? If yes, how much?

$\mathrm{x}$. Do you or your parents save the money in bank? If yes, why is it so?

\section{Influence from family/society/organizations}


i. Does your family encourage you to pursue business after you complete your studies?

ii. Does your family member say that making a living by doing business is better than earning a salary form a government job?

iii. Has anyone in your family become a successful entrepreneur/businessperson? (if yes ask the following question)

iv. Do you wish to be a successful entrepreneur like him/her? Why?

\section{Policy matter}

i. Are you aware of any government policies that favor entrepreneurship?

ii. Do you think there is effective government programs aimed at supporting new and growing business?

iii. Do you think the support for new and growing business is a high priority for the government?

\section{E. Support from government and financial institutions}

i. Do you think there are sufficient government subsidies/incentives available for new and growing business?

Do our financial institutions support people with good business ideas? 